\title{
Does Foreign Portfolio Investment Reach Small Listed Firms?
}

\author{
April M. Knill
}

\begin{abstract}
Using a unique dataset, the author examines the impact of foreign portfolio investment on the capital issuance behavior of small listed firms. The author finds that foreign portfolio investment is associated with an increased probability of small firm security issuance in all nations, regardless of property rights development. Evidence suggests the mechanism by which this occurs is a freeing up of capital in domestic markets when large firms utilize the foreign investment directly. Debt levels in nations where property rights are more developed increase, suggesting that foreign portfolio investment may reach small firms through the banking channel as well as capital markets in these nations.
\end{abstract}

JEL Classification: D92, F32

Keywords: foreign portfolio investment, access to capital, emerging markets, small firm

World Bank Policy Research Working Paper 3796, August 2008

The Policy Research Working Paper Series disseminates the findings of work in progress to encourage the exchange of ideas about development issues. An objective of the series is to get the findings out quickly, even if the presentations are less than fully polished. The papers carry the names of the authors and should be cited accordingly. The findings, interpretations, and conclusions expressed in this paper are entirely those of the authors. They do not necessarily represent the view of the World Bank, its Executive Directors, or the countries they represent. Policy Research Working Papers are available online at http://econ.worldbank.org. 


\section{Introduction}

The decision to invest abroad is typically a two-step process for investors. First, they decide in which country to invest. Second, they decide in which companies to invest. Studies such as Aggarwal, Klapper, and Wysocki (2005) find that disclosure at the firm level is an important determinant of firm choice for institutional investors. Since information asymmetry appears to be worst for smaller firms, foreign investors often steer clear of these firms, even if they are listed. This implies that investors that are looking for international diversification choose to invest in only the largest listed firms. Indeed, Dahlquist and Robertsson (2001), Kang and Stulz (1997), Edison and Warnock (2004), and Cai and Warnock (2004) all find that foreign owners prefer large firms. Leuz, Lins, and Warnock (2007) find that information asymmetry and monitoring costs lead investors to choose firms with the least opaque earnings, also implying that foreign investment would go directly to large firms. As such, it isn’t immediately obvious whether small listed firms would benefit from foreign portfolio investment, defined by the International Monetary Fund as equity and debt issuances including country funds, depository receipts, and direct purchases by foreign investors of less than 10\% control (Balance of Payments Manual, 1993). This is especially the case in countries where property rights are less strictly enforced.

Although the likelihood of small firms accessing foreign capital directly is very small, foreign portfolio investment (FPI) could have implications on capital allocation in the domestic market. Wurgler (2000) finds that financial markets facilitate capital allocation. Since capital market liberalization allows for foreign investment and deepens financial markets (Henry, 2000), ${ }^{1}$ one could argue that FPI could improve capital allocation. Thus, small public firms could see an improvement in their access to capital with an increase in the level of FPI. ${ }^{2}$

This suggests that FPI could actually improve access to finance for small listed firms. If FPI is beneficial to the access to financing of small listed firms, by what mechanism does it help? Does the impact of FPI on the access to financing of small listed firms change depending on the level of property rights protection? To answer these questions, this paper examines the impact of FPI on the access to 
financing of small listed firms. ${ }^{3}$ Specifically, I examine the extent to which FPI can help small public firms obtain financing for growth, even when markets and institutions in their countries are underdeveloped. I further examine which route this potential benefit takes: (1) through the capital markets, or (2) through bank lending. Finally, I examine whether the mechanism by which this benefit flows is through the availability of capital in the domestic markets (i.e., capital allocation).

I find that the probability that a small listed firm issues capital in a given year increases with the level of FPI (scaled by the nation’s GDP). This relationship exists regardless of the development of property rights in the firm's domicile nation. The route that FPI takes to reach small listed firms in nations with less developed property rights (LDPR) is through the capital markets only. This can be seen by the increased probability of domestic capital issuance along with decreased levels of short-term, long-term, and total debt. The route that FPI takes to reach small listed firms in nations with developed property rights (DPR) is through both capital markets and bank lending. Results show an increased probability of domestic capital issuance in these nations, as well as an increase in both long-term and total debt levels. The latter result implies that both the frequency and maturity of loans through banks and other financial institutions is increasing with FPI in these nations. These results lend support to the proponents of FPI and liberalization, casting doubt on the popular opinion that "hot money" is detrimental to firms.

This paper contributes to three main areas of literature. The first is that of small firm access to capital. As markets become more integrated, FPI is a potential source of new investment capital for these firms. Information as to whether and how this additional source of capital increases access to financing for small firms is useful in extending this literature.

This work is also related to the literature on global capital flows. As more countries consider reforming foreign investment policy to include foreign investors, this area of research becomes a resource for many. Providing evidence that is consistent with a positive impact of this capital flow at the firm level enhances the debate on the merit of FPI as a vehicle for growth.

Finally, this research touches on that of liberalization. Although this research is not a study on liberalization, it offers insight into the impact of one of the capital flows that might result from the 
opening of a country's borders to foreign investment. Understanding what drives the aftermath of liberalization, such as the impact of a change in FPI, may offer insight into the debate on liberalization.

The papers most related to mine are Harrison, McMillan, and Love (2004) and Laeven (2003). ${ }^{4}$ Although similar in intent, these papers differ from mine on many dimensions. Harrison et al. (2004) focus on the impact of foreign direct investment on the financial constraints of firms. ${ }^{5}$ They examine foreign direct investment cash flows as a proportion of all foreign investment rather than the size of the market in question. ${ }^{6}$ Laeven (2003) examines the impact of liberalization (reform policies that open financial markets to foreign direct and portfolio investment) on financial constraints rather than the specific cash flows resulting from said reformation. My paper differs from these in that I speak to access to capital (versus financial constraints) that can be directly measured by issuance data and accounting levels.

Further, my papers differ from these with regard to data. Both Harrison et al. (2004) and Laeven (2003) use the Worldscope database. Since my emphasis is on small firms, I create a unique database of over 250,000 firm year observations across 43 countries merging two datasets to circumvent the larger firm bias from which many existing international databases suffer.

The rest of the paper is organized as follows. Section 2 describes the mechanism by which FPI may be beneficial to small listed firms. Section 3 describes the empirical methodology. Section 4 describes the data. Section 5 provides the results, Section 6 the robustness analysis, and Section 7, the conclusion.

\section{Small Firm Access to finance}

Small firms tend to be dependent on bank lending to finance their growth (Cull, Davis, Lamoreaux, and Rosenthal, 2005). A portion of small firms reach the capital markets and might use public financing to grow their businesses. Those who do access public capital markets (“listed” firms) might still rely, at least in part, on bank lending to finance their growth. As such, I examine two ways in 
which FPI might reach the small firm: (1) through the capital markets, and (2) through banks, which, in turn, invest in or extend more credit to these small listed firms.

\subsection{Capital Markets}

Generally speaking, FPI flowing into a country increases the supply of capital in that country (ignoring for a moment the mechanism by which this occurs). If a small listed firm is unable to access capital because of capital supply limitations, an infusion of capital (i.e., in this case FPI) would increase the likelihood that a firm would be able to issue capital. ${ }^{7}$ Empirically stated,

H1. The probability of domestic capital issuance for small listed firms is significantly positively related to the level of FPI (scaled by the size of its domicile nation).

The mechanism by which an increase in FPI could reach small firms is through a freeing up of domestic capital. This results from large firms (and likely only these firms) gaining access to the increased foreign capital. The additional capital supplied to large firms potentially frees up capital in the domestic market that would otherwise be absorbed by those large firms, implying a shift in capital allocation similar to that in Wurgler (2000). This may be tested empirically by evaluating whether large firms are less likely to issue capital domestically when FPI increases. Empirically stated this becomes:

H2. The probability of domestic capital issuance for large listed firms is significantly negatively related to the level of FPI (scaled by the size of its domicile nation).

\subsection{Bank Lending}

For those small firms who are dependent on bank lending and/or remain unable to access publicly issued securities on a regular basis, the path of FPI through capital markets is potentially irrelevant. Instead, a path through financial institutions is relevant. The theory which motivates this path of 
investment can be found in the bank lending theory of monetary policy (Bernanke and Blinder, 1988; Kashyap and Stein, 1995; Gambacorta and Mistrulli, 2004). Kashyap and Stein (2000) find that small banks are exceptionally sensitive to monetary policy. This is relevant as they are the banks inclined to serve small firms (see, e.g., Berger, Miller, Petersen, Rajan, and Stein (2005) and Peek, J. and E.

Rosengren (1995)). The lending theory finds that money supply tightening (expansion) appears to decrease (increase) the ability of banks to loan funds based on the relative illiquidity (liquidity) of their balance sheets. This implies that a positive money shock in a country will cause bank balance sheets to be relatively more liquid. This, in turn, enables them to increase the amount of credit extended to the public, or to "risk shift" their portfolio, extending more and/or longer-term debt to previously perceived "risky” clients.

Although this money supply augmentation is due to monetary policy in Kashyap and Stein’s (2000) paper, this theory could arguably be extended to a different source of money supply augmentation: foreign portfolio inflows. An increase in the liquidity of a bank's balance sheet through increased outside investment enables them to lend in the same manner as if there were changes in money supply caused by (unsterilized) monetary policy. This can occur through investment in the banking sector or due to the implications increased money supply has on the ability of banks to raise reservable forms of financing. If the amount of credit extended to small listed firms is increased, we would expect to see a corresponding increase in their level of debt, particularly long-term debt. More concisely stated:

H3. Long-term debt levels of small listed firms are significantly positively related to the level of FPI (scaled by the size of its domicile nation). 


\section{Empirical Method}

\subsection{Capital Markets}

To examine the impact of FPI on the access to finance of small listed firms, I focus my analysis on the sub-sample of listed firms that have fewer total assets than the country-year median. Using annual medians within countries allows firms to move into and out of size categories as their assets would allow.

The results of a Durbin-Wu-Hausman test for endogeneity for FPI demonstrate that endogeneity is a concern. In support of this evidence are the results of Agarwal (1997), which indicate that the significant determinants of FPI are the (change in the) real exchange rate, share of the domestic capital market in the world capital market, and some proxy for economic activity. As such, I use an instrumental variable method that in the first stage regresses FPI on the above variables with relative interest rates (annual real interest rates scaled by the annual sample average) serving to explain the economic activity. I also include trailing FPI volatility to predict FPI with its significant determinants (Bekaert and Harvey, 2003; Henry, 2000; Patro and Wald, 2005; Mukherjee, Bose, and Coondoo, 2002). The first stage regression then becomes:

$\mathrm{FPI}_{j, t}=\beta_{0}+\beta_{1} \Delta$ FXRate $_{j, t-1}+\beta_{2}$ Share $_{j, t-1}+\beta_{3}$ RelIntRates $_{j, t-1}+\beta_{4}$ FPIVol $_{j, t-1}+\varepsilon$

To discern the impact of FPI on access to capital, I divide the sample into halves based on property rights (DPR nations are those with property rights = 1 or 2; LDPR nations are those with property rights $=3$ or 4 ). I control for firm, time, and industry fixed effects. I further control for firm-level capital structure choice determinants to ensure that firms issue based on need, not based on capital structure decisions. I use a (IV) probit model due to the limited nature of the dependent variable. The dependent variable in this model is the probability of domestic capital issuance (i.e., $y=1$ if a firm issues and $\mathrm{y}=0$ if it does not). Empirically stated, this becomes: 


$$
\begin{aligned}
\operatorname{Prob}(y=1)_{i, t} & =\Phi(Z B) \\
& =\Phi\left(\gamma_{0}+\gamma_{1} F P I_{j, t-1}+\gamma_{2} X_{i, t-1}+\gamma_{3} Y_{j, t-1}+\gamma_{4} I_{i}+\gamma_{5} t\right)
\end{aligned}
$$

where $\Phi$ represents the standard cumulative normal probability distribution, Z represents a vector of explanatory variables, and B is the vector of coefficients. FPI is the predicted level of FPI as a percentage of GDP resulting from the first stage (Equation 1) of the instrumental variable probit regression. $\mathrm{X}$ is a vector of lagged firm-specific variables such as cash, debt/asset level, risk, profitability, and asset tangibility. These variables are included to control for times when firms would be more likely to issue securities (Korajczyk and Levy, 2003). Y is a vector of lagged macroeconomic variables such as GDP growth, levels of other potential sources of capital such as foreign direct investment, domestic credit, and savings, and investment environment variables including invest, law and order, and corruption levels. ${ }^{8} \mathrm{I}$ is a vector of industry dummies to control for industry effects and t represents time dummies, which control for time effects in the panel. A description of the firm-, industry-, and country-specific variables is in the data section, as well as in the Appendix.

The instrumental probit method uses a bootstrapping method that implements randomly chosen subsamples of the dataset with replacement to avoid dependence on assumptions regarding the normality of the distribution or the absence of stochastic influences on the data. ${ }^{9}$ The bootstrapping technique is vital to ensuring that the standard errors are correct and that the resulting significance is accurate (i.e., not overstated). Based on hypothesis H1, I expect $\gamma_{1}$ to be both positive and significant for small firms in DPR countries, and potentially the same for small firms in LDPR countries.

To test H2, the mechanism by which FPI reaches small listed firms, I need to examine the impact of FPI on the domestic issuance of large listed firms. Since large firms are, in general, not financial constrained, I need to first determine the external financing needs of each firm. Following Beck, Demirgüç-Kunt, and Maksimovic (2002), I discern each firm’s financial need or “external funds 
necessary” (EFN). Beck et al. (2002) derive this value from the "percentage of sales” approach to financial planning, calculating the external funds necessary as follows: ${ }^{10}$

$\operatorname{EFN}_{t}=\left(\varsigma_{t}^{*}\right)$ Assets $_{t}-\left(1+\varsigma_{t}^{*}\right)$ Earnings $_{t} * R R_{t}$

The first term in equation (3) refers to the assets necessary for firm growth. The second term is the internal financing available for said growth. Earnings are after taxes. RR is the retention ratio for the firm. ${ }^{11}$ As noted in Beck et al. (2002), the use of the formula to discern external funds necessary depends on the true values of assets being reported (relative to their depreciable basis). To forecast growth for period $\mathrm{t}, \varsigma_{t}^{*}$, I utilize the fitted values of growth resulting from the following equation:

$G_{i, t}=\alpha_{0}+\beta_{1} X_{i, t-1}+\beta_{2} Y_{j, t-1}+\beta_{3} I_{i}+\beta_{4} t+\varepsilon$

where all variables are as defined in Equation (2). I adopt the Rajan and Zingales (1998) approach to obtain unconstrained growth rates for the sample since using firm-specific information would imply that the resulting predicted growth rates would be optimal. ${ }^{12}$ To that end, fitted growth rates from the results of Equation (4) using U.S. firms only are mapped by both industry and size to all other countries and these observations are subsequently dropped from the analysis. ${ }^{13}$ Doing so avoids any downward bias based on the inclusion of the firms that were used to obtain the unconstrained growth rates.

Using a subsample of only large firms, defined as those firms with total assets greater than the annual country median, I drop those firms whose EFN (as determined in equation (3)) is negative. I then rerun the specification in Equations (1) and (2) to test H2. Based on my hypothesis, H2, I expect $\gamma_{1}$ to be both negative and significant for large firms regardless of property rights development. 


\subsection{Bank Lending}

To address those small firms in my dataset that are at least, in part, reliant on bank debt, I examine the impact of FPI on short-term, long-term, and total debt levels. I examine this impact at the

firm level to observe how total leverage, as well as the maturity of debt, changes with levels of FPI. ${ }^{14} \mathrm{~A}$ decrease in the level of short-term debt, a debt maturity on which these firms most typically depend (Barclay and Smith, 1995), in favor of longer-term debt would imply increased access to finance. Indeed, longer-term debt provides capital over a longer term. Using a similar version of the regression in Equation (2) that uses as its regressand leverage, I regress the following using both OLS and Tobit methodologies:

(Short-term/Long-term/Total) $\operatorname{Lev}_{i, t}=\varphi_{0}+\varphi_{1} \mathrm{FPI}_{j, t-1}+\varphi_{2} X_{j, t-1}+\varphi_{3} Y_{i, t-1}+\varphi_{4} I_{i}+\varphi_{5} t+\varepsilon$

where $\operatorname{Lev}_{\mathrm{i}, \mathrm{t}}$ refers to the amount of leverage (short-term, long-term, and total; each regressed separately) firm i holds at time t. All other variables are as they appear in Equation (2). Real interest rates and fiscal burden, a measure of the average firm's tax burden in a country, are added to the vector of macroeconomic variables, Y, to control for capital choice, as well as overall credit demand/supply issues. Specifically, fiscal burden is added to control for capital issuance choice with regard to tax minimalization. Real interest rates are added to account for the cost of raising debt and the possible implications of those costs on demand. FPI is once again the predicted level resulting from Equation (1). Relative interest rates are excluded due to its potential multicollinearity in Equation (5) once real interest rates are included. If FPI enhances the access to finance of small listed firms through an extension of the maturity of their outstanding debt, $\varphi_{1}$ will be positive in specifications using long-term debt as the regressand. $\varphi_{1}$ will be negative in specifications using short-term debt as the regressand. 


\section{Data}

I obtain issuance data from the Securities Data Corporation (SDC) Global New Issues database for the time period 1/1/1996-8/31/2005. ${ }^{15}$ Following many empirical studies in corporate finance, I exclude regulated industries such as financial services and utilities firms. These firms do not operate in the same manner as unregulated firms and would likely confound the results if included. I also exclude those firms that have gone bankrupt because of the special set of issues that are included in capital structure determination when a company is failing. This exclusion follows the method of Asquith, Gertner, and Scharfstein (1994) who find that such situations generally cause a major restructuring of capital structure outside of the scope of financial constraint relaxation.

I collect over 49,000 domestic issuance observations of common stock, non-convertible debt, convertible debt, non-convertible preferred stock, and convertible preferred stock. The exclusion of international issuances is intentional due to the endogeneity between FPI and international issues. Only one issue per year is retained for each company to avoid upward bias in the results toward issuing capital. Dropping multiple issuance observations for firm years leaves 32,703 observations. Financials for the companies issuing domestically are hand collected from Reuters. This approach, although extremely time consuming, provides a much richer sample than afforded by SDC Platinum alone. Reuters provides financial information on all publicly traded firms for the majority of countries in the world and, as such, does not suffer from the bias toward large firms that other international databases such as Worldscope/Datastream/Research Insight do. In fact, according to Reuters, financials are provided for over $90 \%$ of the firms covered. A list of the cumulative firm year issuances by country is provided in Table 1.

(Insert Table 1 about here)

The only firms not covered in Reuters are those that have gone bankrupt or have merged with another firm. Bankrupt firms are deliberately excluded from the sample as previously mentioned above. 
The absence of merged firms would only be a problem if the issuing company had acquired a firm (or was acquired by a firm) that is vastly different in its issuing behavior than the remainder of the sample.

Adding to the 32,703 observations of capital issuance, I collect data for those years that these issuing companies do not issue to create a panel dataset. ${ }^{16} \mathrm{I}$ also collect data on firms not issuing capital during the sample period (1996-2005) to represent those public companies that either cannot issue capital or have sufficient funds internally. When these non-issuer firm-year observations are included to my dataset, the number of observations exceeds 250,000 firm-year observations.

Seven countries out of the original 53 are dropped due to insufficient data. ${ }^{17}$ In these cases, there are only one or two observations of capital issuance, not enough from which to obtain any statistically significant results. Two more countries, Taiwan and Bermuda, are dropped due to insufficient macroeconomic data. The exclusion of these countries decreases the sample size by 3,294 firm year observations, which is less than $2 \%$ of the overall sample.

Cross-country studies that examine equity issues often exclude Australia due to their unique form of equity rights issues. This form of offering allows the existing shareholders to decide whether they would like to accept a certain amount of shares based on a pre-determined ratio at a price lower than market value. These equity offerings are typically excluded (or the entire country in the cross-country sample) as it affects firm fundamentals such as share capital, book value per share, earnings per share, and the liquidity of the stock. The inclusion of these observations would clearly bias the results, so they are excluded. With the exclusion of Australia, the number of countries in the final sample is 43.

Firm-level data are winsorized at $1 \%$ to minimize the biasing impact of outliers. A full list of summary statistics for the dataset is provided in Table 2.

(Insert Table 2 about here) 


\subsection{Firm-Specific Information}

Databases, such as Reuters, obtain financials for these listed companies from the exchanges. To the extent that these exchanges have different reporting requirements, financial definitions might vary. Differences in currency value are avoided by using ratios, which are comparable across countries. Ratios are obtained by scaling by total assets unless otherwise noted.

As many empiricists have attributed size as a determinant of capital structure, which could have implications on capital issuance, I assign size categories based on total assets. Korajczyk and Levy (2003) and Baker and Wurgler (2002) find a positive relation between leverage and size. Titman and Wessels (1988) find that size influences not only the extent of leverage, but also the type. ${ }^{18}$ Firms that have total assets less (more) than the country-year median are classified as Small (Large).

Leverage itself plays a role in the timing of issuance for many firms as found in the market timing literature (Leary and Roberts, 2005; Korajczyk and Levy, 2003; Baker and Wurgler; 2002). I include this variable to control for any implications market timing or capital structure may have on firm issuance.

Profitability of firms would be an obvious influence since it impacts how well a firm could fund positive net present value (NPV) projects internally (i.e., avoiding external fundraising). Following Titman and Wessels (1988), I calculate this variable as operating income divided by sales. Another obvious influence is the perceived level of risk for a firm. I calculate this as the standard deviation of the return on assets for time $\mathrm{t}-3$ through time t-1.

Also relevant is asset tangibility. This variable refers to how palpable the assets of a firm are and relates to a small firm's access to capital concerns through its limitations on debt levels based on the ability to provide collateral. A firm with fewer tangible assets is thought to have an increased probability of bankruptcy since it would have less ability to raise funds through liquidation in times of financial distress. I calculate this variable by dividing fixed assets by the book value of assets (following Rajan and Zingales, 1995).

To correct for any additional access a firm might have in other nations (Lins, Strickland, and Zenner, 2005), it is vital to include an indication of whether a firm has listings in other countries (e.g., an 
American Depository Receipt on a U.S. stock exchange for a non-U.S. firm). ${ }^{19}$ Thus, I have included a dummy variable for cross-listing that takes on a value of one if a firm is listed on an exchange outside of its nation of domicile and zero otherwise.

\subsection{Industry Information}

Differences in industry classification are avoided by using the issuers' (one digit) primary SIC code as an industry indicator. Industry dummies are included to account for any industry fixed effects.

\subsection{Macroeconomic Information}

To control for the impact of other potential sources of funds for firms, I include savings, domestic credit, and foreign direct investment. Savings is calculated as the difference between gross domestic product and consumption. Domestic credit is the level of credit extended by financial institutions domestically. Foreign direct investment is included to control for the effect provided by the more stable of the two global capital flows on capital issuance. This inclusion is important given the fact that the impact of foreign direct investment is likewise beneficial for alleviating financing constraints (Harrison et al., 2004). To control for business cycle effects, I include GDP growth.

Fiscal burden, from Heritage Foundation, is used to control for the tax implications of debt in the bank-lending route of FPI analysis. This variable takes into consideration the proven relation between taxes and lending in a multinational setting (Desai, Foley, and Hines, 2004).

Controlling for the investment environment, I include investment, law and order, and corruption, which are indices reflecting the investment risk facing foreign investors, the level of legal development, and the level of corruption, respectively, in a country. All three indices are created by the International Country Risk Guide and collectively reflect the investment environment of a country. The inclusion of proxies for the extent to which a country's investment environment attracts investors follows the method of Beck et al. (2002) and Beck et al. (2005), as well as many other examinations of access to financing in 
an international setting. Papers such as Claessens and Laeven (2003), and La Porta, Lopez-de-Silanes, Shleifer, and Vishny (1997) point out the importance of the investment environment as a determinant of financial development.

The variable of interest in this study, FPI, is included in its net form (inflows minus outflows) for the countries in the sample. This data was collected from World Bank’s World Development Indicators and includes debt and equity investments made by investors foreign to the issuer's domicile nation. Figures are given as net levels and are scaled by a proxy for the size of the nation, the country’s GDP. Instruments of the variable of interest are included due to the endogenous nature of FPI. Relative interest rates are included to control for investor demand for interest-bearing securities in the firm's domicile nation versus those of other countries (Samak and Helmy, 2000). Share is included to address the attractiveness of a given economy based on market capitalization (generally in more developed capital markets), or the decrease in the cost of equity and the resulting increase in the price of existing shares that occurs with market integration (Patro and Wald, 2005; Henry, 2000). To provide an additional determinant of international trade/investment, I include the change in real foreign exchange rates to provide a meaningful value indicator of capital investments (Agarwal, 1997). FPI volatility is calculated as the variance of FPI levels for the trailing three year term (time t-3 through t-1). These scaled values are used to elicit predicted values of scaled net foreign portfolio capital flows based on the work of Agarwal (1997). Bekaert, Harvey, and Lundblad (2003), Henry (2000), Patro and Wald (2005), and a host of other papers address this multi-faceted environment.

The basis of nation type for the analysis, property rights, is used to examine the ultimate impact of the importance of the development of the same. This variable is chosen following La Porta et al. (1997) and La Porta, Lopez-de-Silanes, and Shleifer (2006), who find the importance of security law and investor protection significant. This variable is an appraisal by the Heritage Foundation of the level of freedom an individual has to accumulate personal property. It is based on the extent and enforcement of laws designed to protect property accumulation. Specifically, it takes into consideration the independence of a country’s judiciary system as well as the ability of an individual to enforce his right to hold property 
through contracts. The level of corruption in the country is also taken into consideration. The index uses a scale from 1 (maximum freedom) to 5 (minimum freedom). The sample used in this paper includes countries with scores between 1 and 4.

Descriptions, as well as sources, of both firm-specific and macroeconomic variables and definitions of financial data used in the analysis are provided in Appendix A.

(Insert Appendix A about here)

\subsection{Data Correlation}

Table 3 provides correlation matrices for all variables used in the analysis. There are no notable significant relationships in the firm-specific data. The only variables that exhibit significant correlation are some of the macro variables. The correlation of several macroeconomic variables is significant and is generally an issue in many international studies. As a result, empirical examinations using different specifications, including select macroeconomic variables and the subsequent addition of problematic variables, are used to provide robustness to the results given the potential empirical biases based on the correlation between the macroeconomic independent variables.

(Insert Table 3 about here)

\section{Results}

\subsection{The Impact of FPI on Capital Issuance}

Intuitively appealing is the fact that in DPR nations, variables such as leverage and cash are significantly positively related, and risk and profitability are significantly negatively associated with capital issuance. In LDPR nations, there are fewer significant firm level variables suggesting that access to capital has less to do with these characteristics and more to do with country-level influences and 
infrastructure. Leverage and cash are exceptions, exhibiting a significant positive and negative relationship with capital issuance, respectively. Overall, firm level variables exhibit the expected marginal coefficients and, as such, are left out for brevity.

Coefficients on macroeconomic control variables exhibit reasonable signs. In LDPR nations [see Table 4, specifications (5) through (8)], domestic credit exhibits a negative association with capital issuance, demonstrating that bank credit is a substitute for accessing capital from the public markets in these nations. In DPR nations [specifications (1) through (4)], domestic credit serves as an additional source of capital as demonstrated by the positive significant coefficients. Savings has a positive significant association with capital issuance in LDPR nations demonstrating that savings is yet another source of capital which provides liquidity for a nation. Interestingly, foreign direct investment only has a significant (marginal) impact in LDPR nations. GDP growth in DPR nations is positive and significant suggesting that when times are good, firms issue securities to fund growth (perhaps suggesting market timing). GDP growth in LDPR nations, however, is largely insignificant. This could be due to the fact that firms in these nations are typically more constrained, needing funding for growth in both good times and bad.

The results of the analysis support the contention that FPI increases the access to financing of small listed firms. The marginal effect of FPI (scaled by GDP) shown in Table 4 is positive and significant. Indeed, the probability that a small listed firm issues in a given year increases by $2.25 \%$ with a one standard deviation increase in FPI standardized by GDP [see Specification (1)]. ${ }^{20}$ Controlling for the investment environment variables such as investment, law and order, and corruption does not change the magnitude or the significance of the impact of FPI on access to finance [see Specifications (2)-(4)].

Looking to LDPR nations in Table 4, we again see a positive marginal effect of FPI. The magnitude for these firms, however, is considerably greater. Indeed, a one standard deviation increase in FPI (scaled by GDP) results in an increased probability of issuance of 22.54\% [see Specification (5)]! Adding investment environment control variables, we see economically important impacts ranging from 19.28\%-28.37\% [see Specifications (6)-(8)]. First stage results may be found in Appendix B. Partial 
scatter plots derived from Specification (1) of Table 4 complement the analysis and may be found in Figure 1.

(Insert Appendix B about here)

(Insert Figure I about here)

It is interesting to note the impact of the investment environment (Investment, Law and Order, Corruption) on small firm access to finance. For DPR nations, the stronger the legal system and the greater the observance of the law, the less likely it is that a small listed firm will issue securities. This could suggest that large firms have more influence on the laws that are put into place with regard to securities. In LDPR nations, investment has a negative and significant coefficient, implying that as a government's attitude toward inward investment improves, small firms will be less likely to issue securities. It is possible that this variable describes more the government's attitude toward foreign direct investment (versus foreign portfolio investment). Governmental policies put into place to level the playing field for foreign (direct) investors can increase competition and squelch investment. Indeed, Agosin and Machado (2005) find that foreign direct investment can, in some cases, actually hinder domestic investment. The coefficient on corruption is also negative for LDPR nations. This is likely due to the fact that bribery may have an instrumental role in small firms accessing capital in these nations.

(Insert Table 4 about here)

These impacts, taken collectively, imply that FPI reaches small firms in both DPR and LDPR nations directly through the capital market, effectively increasing the access to finance for small listed firms. This implies that the financial markets of the U.S. and other developed nations can confer benefits on developing nations by helping to fund the growth of small firms in those nations whose markets cannot perform this function alone. 
Table 5 provides evidence that the mechanism by which FPI reaches small firms is through a freeing up of capital in the domestic market. FPI has a negative impact on the probability of domestic capital issuance for large firms that have a need for external financing. This effect exists marginally in DPR nations, as evidenced by significant coefficients in Specifications (1) and (3). On average, the negative impact of a one standard deviation increase in FPI scaled by GDP is $1.48 \%$ (some specifications lack statistical significance) in these nations. This effect is seen more extensively in LDPR nations [see Specifications (5)-(8)]. The average impact in these nations is $2.36 \%$. This suggests that large firms, which are more than likely the direct beneficiary of an increase in foreign investment, are less likely to issue capital in domestic markets due to their increased access to global capital. Meshing nicely with the results found in Table 4 where small firms in LDPR nations benefited to a greater extent from an increase in FPI, greater statistical significance and greater marginal effects are seen for large firms in LDPR nations.

These results compliment those found in Wurgler (2000), which are that “developed financial markets increase investment more in growing industries.” Although the results in this paper are due to outside capital entering the domestic market and not the domestic market itself developing, the effect on the amount of capital is the same. Likewise, instead of growing industries, we are speaking of growing firms (relative to the large firms). The analogous result found in Wurgler (2000) adds credence to these findings.

(Insert Table 5 about here)

\subsection{The Impact of FPI on Credit Availability}

Table 6 indicates statistically significant evidence consistent with an increase in both long-term debt and total debt in DPR nations. This is seen in a significant increase in the portion of long-term debt [Specification (3) and (4)] as well as the total amount of debt [Specification (5) and (6)] with a 
corresponding increase in FPI. The choice of empirical methodology, either OLS or Tobit, seems to be irrelevant as both methodologies lead to the same qualitative conclusions. These impacts demonstrate some evidence of an extension of the bank lending channel of monetary transmission (Kashyap and Stein, 2000) to generic money shocks in DPR nations. The statistically significant increase in long-term and total debt suggests better access to capital and perhaps a lengthening of the maturity of debt. This could imply that when FPI flows into a DPR country, banks are able to "risk shift" their portfolio to include more risky holdings, potentially including longer-term and/or more frequent loans to small firms. Although part (or all) of this empirical finding could be due to public debt issuance, the dependence of small firms on bank loans suggests that these results are likely due, at least in part, to FPI's influence on bank lending.

The impact of FPI on debt levels in LDPR nations is almost a mirror image to that in DPR nations. All three forms of debt, short-term, long-term, and total debt, appear to be significantly negatively influenced by FPI [see Specifications (7)-(12)]. These findings suggest that an extension of the bank lending channel does not exist in LDPR nations. These results are not surprising considering the volatility of FPI capital flows and the less supportive property rights in these nations. It appears that the same investment environment that limits the amount of FPI that enters a nation precludes any benefits that FPI capital flows might offer through the banking channel. In fact, it suggests that there may be a substitution effect between bank lending and FPI. Giannetti (2007) supports this notion by establishing a reverse relationship between capital inflows and the stability of bank lending in less developed nations.

This effect combined with the results of Table 4, wherein small firms in DPR nations are more able to access capital with a corresponding increase in FPI, suggests that these firms are able to obtain access from the capital markets and, perhaps, additional sources of bank credit. The mechanism by which small listed firms in LDPR nations receive the benefits of FPI, however, is strictly through capital markets. Banks and capital markets seem to be substitutes in these countries. This notion is supported by the coefficient on domestic credit for LDPR nations in Table 4. 
(Insert Table 6 about here)

\section{Robustness}

\subsection{Interactions with Investment Environment Variables}

Examining the interactive effect of FPI with investment environment variables gives us a better idea of the effect of FPI on small firm access to capital across levels of investment environment (i.e., levels of investment, law and order, and corruption variables). Examining the implications of FPI when interacted with these variables on the entire dataset (across firm size and property rights development) offers further insight into the importance of the investment environment.

The results are similar to those of La Porta et al. (1997), Bekaert and Harvey (2003), and Wurgler (2000). The impact of FPI including investment (a variable that refers to a government's attitude toward foreign investment and the resulting risk of foreign investment in that country) is one that implies decreasing margin to return. For those governments that are hostile to foreign investment (e.g., investment = sample mean minus the sample standard deviation), the marginal impact of FPI on access to capital is large, $8.71 \%$ for each standard deviation increase in FPI. For those governments already open to FPI, the marginal effect of becoming more so is less. Those governments with an investment index equal to the sample mean plus the sample standard deviation would see only a $0.92 \%$ marginal benefit of a one standard deviation increase in FPI.

The impact of FPI given corruption is also influential. The cumulative impact suggests that the impact of FPI in the presence of this variable is pivotal. For example, looking to those nations where corruption is rampant (e.g., corruption = sample mean minus sample standard deviation), the cumulative impact of a one standard deviation increase in FPI is positive for firm access to capital (3.09\%). In those nations where corruption is well under control (e.g., corruption = sample mean plus sample standard deviation), the impact is equally large with regard to magnitude, but negative at $-2.98 \%$. These results suggest that there are decreasing returns to scale for corruption as well. In fact, nations with a corruption 
index slightly higher than the mean (i.e., lower levels of corruption) no longer receive a marginal benefit from FPI if they continue to clean up corruption.

The impact of FPI given a law and order scenario appears to be the most relevant investment environment variable. It, too, possesses decreasing returns to scale. Firms in nations where this index is low (e.g., law = sample mean minus sample standard deviation) can expect a $3.41 \%$ increase in access to capital with a one standard deviation increase in FPI. Those nations where law and order is more developed (e.g., law = sample mean plus sample standard deviation), however, will see a $13.27 \%$ decrease with a one standard deviation increase in FPI. This once again suggests that law and order is important to a certain point. Beyond that point, improvements in law and order can actually limit the allocation of capital that results from FPI. Results can be found in Table 7.

\section{(Insert Table 7 about here)}

\subsection{Definitions of Key Variables}

\subsubsection{FPI Definition}

Performing sensitivity analysis around the definition of the key variable, FPI, provides robustness for the results. I use three alternate definitions for FPI: (1) FPI net flows scaled by gross private capital flows into a nation, (2) the base definition (i.e., FPI/GDP) winsorized at 1\%, and (3) percentage change in FPI net flows. The first definition is the same as that used in Harrison et al. (2004). Using this definition, the majority of the results remain. The only significant difference is found in Specification (6). The coefficient on FPI is no longer significant as it was in Table 4. This answer reconciles the results found in this paper with those in Harrison et al. (2004). I interpret this difference not as a weakening of the implications of this paper, but as a clarification of what is important with regard to FPI and access to capital. Specifically, this difference would suggest that it is not the portion of FPI in total capital flows that matters with regard to access to capital, but rather the level of FPI relative to the size of the nation that is important. The second definition provides results that are qualitatively identical to the results found 
in Tables 4-6. The last definition leads to results that are identical save those for large firms in LDPR nations. The coefficient in this specification is no longer significant, once again pointing to the relevance of the FPI flow relative to the size of the nation. Results are provided in Table 8, Panel A.

(Insert Table 8 about here)

\subsubsection{FPI Volatility Definition}

Altering the definition for FPI volatility by lengthening the term over which volatility is calculated (from three years) to five years does not qualitatively change the results. This adds to the credence of our results and allays fears that noise in the calculated volatility does not bias the results. Results are provided in Table 8, Panel A.

\subsection{Sample Inclusion}

\subsubsection{Excluding Countries with Capital Control Changes}

To see if the test results are sensitive to sample country inclusion criteria, I drop countries that might bias results due to changes in capital control policy or the existence of specific laws that may bias results such as those in China where only B shares were offered on the market for foreign investors during this term and foreign banking was not possible before 2002. Dropped countries in this specification include China, Hong Kong, South Korea, and Chile. ${ }^{21}$ Results in DPR nations remain constant. In LDPR nations, however, results change considerably. Specifically, the coefficient on FPI when regressed on long-term debt [Specification (9)] is no longer significant and the coefficients on FPI when regressed on both short-term and total debt [Specifications (8) and (10)] turn positive. Assuming legitimate arguments for the exclusion of these countries with capital control changes, weak evidence of the bank lending channel could be seen. Although a lengthening of the maturity of debt is not seen, i.e., no significance in 
Specification (9), a statistically significant increase in both short-term and total debt in LDPR nations in definitely encouraging. Results can be found in Table 8, Panel B.

\subsubsection{Size Groupings}

Changing the definition of "Small" from less than the country-year median to the bottom tercile of firms in each country-year, results change slightly. In LDPR nations, the coefficient on FPI when regressed on short-term debt [Specification (8)] is no longer significant. This does not materially change the implications put forth in the credit availability section since the evidence found in the base specifications (Table 6) did not support the bank lending channel in these (LDPR) nations. Results are provided in Table 8, Panel B.

\subsubsection{Equity Issues Only}

To address concerns that the inclusion of all types of capital issuances might be problematic, I rerun the base specifications for Tables 4-6 using only equity issuances. Results are identical with regard to statistical significance and vary only slightly with regard to magnitude of the marginal effects. This serves to reinforce the results, and suggests that lumping the issuance of several types of capital together in this analysis does not bias the results. Results are provided in Table 8, Panel B.

\subsection{Methodology Extrapolation}

\subsubsection{Clustering at the Industry Level}

To ensure that results are not spurious due to a missing industry-level variable in the specification, I perform the base specification clustering errors at the industry level. Coefficients for industry-level clustering are slightly different due to the absence of industry dummies in these specifications. As is evident from Panel E of Table 8, results for industry clustering differ only with regard to the FPI coefficient when regressed on long-term debt [Specifications (4)]. The coefficient loses 
its significance as compared with that found in Table 6, although it is very close to be significant at the 10\% level. This weakens only slightly the implications regarding FPI reaching small firms through the banking channel in DPR nations. Results are provided in Table 8, Panel C.

\subsubsection{Country Dummies}

Including country dummies to ensure that there is not a missing country-level variable biasing results, results change only slightly. Only the coefficients for FPI regressed on long-term debt change materially [Specification (4) and (8)]. Specifically, they lose statistical significance as the impact of the country specifics subsumes the impact of FPI on long-term debt. That said, results with country dummies should be taken lightly since there is a much greater chance of multicollinearity. I include these results for the sake of thoroughness only. Results are provided in Table 8, Panel C.

\subsubsection{Frequency Weights}

To ensure that the diversity in the number of observations per country is not confounding the results, I add frequency weights to the analysis done in Tables 4-6. This methodology accounts for the frequency of country observations to ensure that diversity in the number of observations across countries does not bias results. Coefficients, as well as significance levels (1\%), remain for all specifications except for Specification (2). Using the frequency weights, the significance of the coefficient on FPI for large firms is now at $1 \%$. In Table 5 [Specification (1)], this coefficient was significant at $5 \%$. This suggests that the frequency of country observations could be biasing the results for large firms. Once the regression methodology controls for differences in the number of observations per country, results are stronger. Results are provided in Table 8, Panel C. 


\section{Conclusions}

Small firms play a distinctive and influential role in both the present and future economic situations in which nations find themselves. Access to financing for these firms is exacerbated by both firm- and macro-level influences. As such, supplementary sources of financing that either directly or indirectly improve the access to finance of small listed firms are worthy of investigation. Examining the importance of FPI in the capital issuance process, I find that FPI enhances the access to finance for small listed firms in countries across property rights development. Results suggest that the route that FPI takes to reach small listed firms is through capital markets. An additional route through the bank lending channel exists in nations with developed property rights. The mechanism by which this occurs appears to be through a freeing up of domestic capital. This result is particularly apparent in nations with less developed property rights.

The positive influence of FPI on small firm access to capital supports the ideals of those who strive for optimal policy reformation in nations that do not support foreign investment and in markets that are excessively volatile or underdeveloped with regard to investor property rights. Easing FPI restrictions on capital flows, stabilizing these investment cash inflows, and improving the treatment of foreign companies and investors could have a very real influence on the longevity of the small firm. 


\section{Appendix A: Variable Definitions}

Panel A: Firm- and Industry-Specific

\begin{tabular}{|c|c|c|}
\hline Variable & \multicolumn{2}{|l|}{ Definitions } \\
\hline Asset tangibility & \multicolumn{2}{|c|}{$\begin{array}{l}\text { Fixed assets divided by the book value of total assets; industry average is used in cases of missing data. } \\
\text { FA/TA }\end{array}$} \\
\hline Cash & \multicolumn{2}{|l|}{ Cash or cash-equivalent divided by total assets. Cash/TA } \\
\hline Cross-listing & \multicolumn{2}{|l|}{ Dummy variable equal to one if a firm has stock listed on foreign exchanges and zero otherwise. } \\
\hline Leverage & \multicolumn{2}{|c|}{ The logarithm of total liabilities divided by total assets. In(Short-term, Long-term or Total) Liabilities/TA } \\
\hline Profitability & \multicolumn{2}{|l|}{ Operating income divided by sales. OpInc/Sales (in Thous) } \\
\hline Risk & \multicolumn{2}{|c|}{$\begin{array}{l}\text { The log of the variance of the firm's profitability ratio over the three years prior to issue; industry average is } \\
\text { used in cases of missing data. } \ln \left(\operatorname{var}\left(R O A_{t}, R O A_{t-1}, R O A_{t-2}\right)\right)\end{array}$} \\
\hline Industry & \multicolumn{2}{|l|}{ Primary 1 digit SIC codes. } \\
\hline \multicolumn{3}{|c|}{ Panel B: Macroeconomic } \\
\hline Variable & Definitions & Source \\
\hline Corruption & $\begin{array}{l}\text { An index from } 0 \text { (most) to } 6 \text { (least) of perceived corruption in a country based on the } \\
\text { likelihood of solicited bribes from a country in relation to such factors of business as } \\
\text { exchange controls, tax assessment, and loan protection. }\end{array}$ & $\begin{array}{l}\text { International Country } \\
\text { Risk Guide }\end{array}$ \\
\hline $\begin{array}{l}\text { Domestic } \\
\text { Credit }\end{array}$ & $\begin{array}{l}\text { Credit provided by financial institutions, with the exception of credit to the central } \\
\text { government, scaled by gross domestic product. }\end{array}$ & WDI \\
\hline Fiscal Burden & $\begin{array}{l}\text { A score from } 1 \text { (low) to } 5 \text { (high) assigned to a country based on the income tax rates, } \\
\text { corporate tax rates, and government expenditures as percentage of output. }\end{array}$ & Heritage Foundation \\
\hline FDI & $\begin{array}{l}\text { Foreign direct investment is investment by investors outside the home country that is } \\
\text { concerned with longer-term ownership or a controlling interest of more than } 10 \% \text {. }\end{array}$ & WDI \\
\hline FPI & $\begin{array}{l}\text { Foreign portfolio investment excluding liabilities constituting foreign authorities' } \\
\text { reserves covers transactions in equity securities and debt securities. Data are in current } \\
\text { U.S. dollars and are scaled by gross domestic product. }\end{array}$ & WDI \\
\hline FPI Volatility & The variance of FPI net flows from time t-3 through t-1. & $\begin{array}{l}\text { WDI; own } \\
\text { calculation }\end{array}$ \\
\hline GDP Growth & GDP per capital growth (\%). & WDI \\
\hline Invest & $\begin{array}{l}\text { A measure from } 0 \text { (worst/closed) to } 12 \text { (best/open) of the government's attitude toward } \\
\text { inward investment as determined by four components: } 1 \text { ) the risk to operations, 2) } \\
\text { taxation, 3) repatriation, and 4) labor costs. }\end{array}$ & $\begin{array}{l}\text { International Country } \\
\text { Risk Guide }\end{array}$ \\
\hline Law & $\begin{array}{l}\text { An index from } 0 \text { (less) to } 6 \text { (more) of law of a nation. It is two measures comprising } \\
\text { one risk component. Each sub-component equals half of the total. The "law" sub- } \\
\text { component assesses the strength and impartiality of the legal system, and the "order" } \\
\text { sub-component assesses popular observance of the law. }\end{array}$ & $\begin{array}{l}\text { International Country } \\
\text { Risk Guide }\end{array}$ \\
\hline $\begin{array}{l}\text { Property } \\
\text { Rights }\end{array}$ & $\begin{array}{l}\text { A score measuring the efficacy of law in enforcing contracts (1- very effective: } 5 \text { - } \\
\text { very ineffective). }\end{array}$ & Heritage Foundation \\
\hline $\begin{array}{l}\text { Real Interest } \\
\text { Rates }\end{array}$ & Annual interest rates adjusted for inflation. & WDI \\
\hline $\begin{array}{l}\text { Relative } \\
\text { Interest Rates }\end{array}$ & Annual real interest rates scaled by annual sample average. & WDI \\
\hline Savings & $\begin{array}{l}\text { Gross domestic savings are calculated as GDP less final consumption expenditure } \\
\text { (total consumption) as a percentage of GDP. }\end{array}$ & WDI \\
\hline Share & $\begin{array}{l}\text { A country's market capitalization divided by the average market capitalization of the } \\
\text { world. }\end{array}$ & $\begin{array}{l}\text { WDI; own } \\
\text { calculation }\end{array}$ \\
\hline $\begin{array}{l}\Delta \text { Exchange } \\
\text { Rates }\end{array}$ & $\begin{array}{l}\text { The annual percentage change in the official exchange rate as determined by national } \\
\text { authorities or the rate determined in the legally sanctioned exchange market (annual or } \\
\text { averaged annually from monthly rates). }\end{array}$ & WDI \\
\hline
\end{tabular}


Appendix B: First Stage Regression for FPI Levels

\begin{tabular}{|c|c|c|c|c|c|c|c|c|}
\hline & \multicolumn{4}{|c|}{ Developed Property Rights $(\mathrm{N}=57,247)$} & \multicolumn{4}{|c|}{ Less Developed Property Rights $(\mathrm{N}=9,169)$} \\
\hline & 1 & 2 & 3 & 4 & 5 & 6 & 7 & 8 \\
\hline GDP Growth & $\begin{array}{c}-0.096 * * * \\
{[0.005]}\end{array}$ & $\begin{array}{c}-0.077 * * * \\
{[0.005]}\end{array}$ & $\begin{array}{c}-0.055^{* * * *} \\
{[0.005]}\end{array}$ & $\begin{array}{c}-0.089 * * * \\
{[0.005]}\end{array}$ & $\begin{array}{c}0.138 * * * \\
{[0.009]}\end{array}$ & $\begin{array}{c}-0.001 \\
{[0.011]}\end{array}$ & $\begin{array}{c}0.121^{* * *} \\
{[0.009]}\end{array}$ & $\begin{array}{c}0.079 * * * \\
{[0.009]}\end{array}$ \\
\hline Foreign Direct Inv. & $\begin{array}{c}0.387 * * * \\
{[0.009]}\end{array}$ & $\begin{array}{c}0.449 * * * \\
{[0.009]}\end{array}$ & $\begin{array}{c}0.330^{* * *} \\
{[0.009]}\end{array}$ & $\begin{array}{c}0.381^{* * *} \\
{[0.009]}\end{array}$ & $\begin{array}{c}-0.069 * * * \\
{[0.008]}\end{array}$ & $\begin{array}{c}-0.067 * * * \\
{[0.007]}\end{array}$ & $\begin{array}{c}-0.083 * * * \\
{[0.008]}\end{array}$ & $\begin{array}{c}-0.076 * * * \\
{[0.008]}\end{array}$ \\
\hline Domestic Credit & $\begin{array}{c}0.007^{* * *} \\
{[0.000]}\end{array}$ & $\begin{array}{c}0.006^{* * *} \\
{[0.000]}\end{array}$ & $\begin{array}{c}0.007^{* * *} \\
{[0.000]}\end{array}$ & $\begin{array}{c}0.005^{* * *} \\
{[0.000]}\end{array}$ & $\begin{array}{c}0.031^{* * *} \\
{[0.001]}\end{array}$ & $\begin{array}{c}0.027 * * * \\
{[0.001]}\end{array}$ & $\begin{array}{c}0.030 * * * \\
{[0.001]}\end{array}$ & $\begin{array}{c}0.038 * * * \\
{[0.001]}\end{array}$ \\
\hline Savings & $\begin{array}{c}-0.315^{* * *} \\
{[0.002]}\end{array}$ & $\begin{array}{c}-0.358 * * * \\
{[0.003]}\end{array}$ & $\begin{array}{c}-0.343 * * * \\
{[0.002]}\end{array}$ & $\begin{array}{c}-0.330 * * * \\
{[0.002]}\end{array}$ & $\begin{array}{c}-0.184 * * * \\
{[0.004]}\end{array}$ & $\begin{array}{c}-0.149 * * * \\
{[0.004]}\end{array}$ & $\begin{array}{c}-0.183 * * * \\
{[0.004]}\end{array}$ & $\begin{array}{c}-0.179 * * * \\
{[0.004]}\end{array}$ \\
\hline Share & $\begin{array}{c}-0.008^{* * *} \\
{[0.000]}\end{array}$ & $\begin{array}{c}-0.005^{* * *} \\
{[0.000]}\end{array}$ & $\begin{array}{c}-0.007 * * * \\
{[0.000]}\end{array}$ & $\begin{array}{c}-0.007 * * * \\
{[0.000]}\end{array}$ & $\begin{array}{c}-0.006^{* * *} \\
{[0.000]}\end{array}$ & $\begin{array}{c}-0.008 * * * \\
{[0.000]}\end{array}$ & $\begin{array}{c}-0.005^{* * *} \\
{[0.000]}\end{array}$ & $\begin{array}{c}-0.014 * * * \\
{[0.001]}\end{array}$ \\
\hline$\Delta$ FXChg & $\begin{array}{c}0.087^{* * *} * \\
{[0.003]}\end{array}$ & $\begin{array}{c}0.106^{* * *} \\
{[0.003]}\end{array}$ & $\begin{array}{c}0.071^{* * *} \\
{[0.003]}\end{array}$ & $\begin{array}{c}0.092^{* * *} \\
{[0.003]}\end{array}$ & $\begin{array}{c}-0.030 * * * \\
{[0.001]}\end{array}$ & $\begin{array}{c}-0.025^{* * *} \\
{[0.001]}\end{array}$ & $\begin{array}{c}-0.031 * * * \\
{[0.001]}\end{array}$ & $\begin{array}{c}-0.029 * * * \\
{[0.001]}\end{array}$ \\
\hline RelIntRates & $\begin{array}{c}0.818^{* * *} \\
{[0.043]}\end{array}$ & $\begin{array}{c}0.633^{* * *} \\
{[0.043]}\end{array}$ & $\begin{array}{c}0.388^{* * *} \\
{[0.045]}\end{array}$ & $\begin{array}{c}0.625^{* * *} \\
{[0.044]}\end{array}$ & $\begin{array}{c}-0.084^{* * *} \\
{[0.007]}\end{array}$ & $\begin{array}{c}-0.024 * * * \\
{[0.008]}\end{array}$ & $\begin{array}{c}-0.068 * * * \\
{[0.008]}\end{array}$ & $\begin{array}{c}-0.113^{* * *} \\
{[0.007]}\end{array}$ \\
\hline FPIVol & $\begin{array}{c}-0.028 * * * \\
{[0.000]}\end{array}$ & $\begin{array}{c}-0.029 * * * \\
{[0.000]}\end{array}$ & $\begin{array}{c}-0.029 * * * \\
{[0.000]}\end{array}$ & $\begin{array}{c}-0.028 * * * \\
{[0.000]}\end{array}$ & $\begin{array}{c}0.020 * * * \\
{[0.002]}\end{array}$ & $\begin{array}{c}0.012 * * * \\
{[0.002]}\end{array}$ & $\begin{array}{c}0.025 * * * \\
{[0.003]}\end{array}$ & $\begin{array}{c}0.030 * * * \\
{[0.002]}\end{array}$ \\
\hline Invest & & $\begin{array}{c}-0.006^{* * *} \\
{[0.000]}\end{array}$ & & & & $\begin{array}{c}0.003 * * * \\
{[0.000]}\end{array}$ & & \\
\hline Law & & & $\begin{array}{c}-0.011 * * * \\
{[0.000]}\end{array}$ & & & & $\begin{array}{c}0.001^{* * *} \\
{[0.000]}\end{array}$ & \\
\hline Corruption & & & & $\begin{array}{c}-0.004 * * * \\
{[0.000]}\end{array}$ & & & & $\begin{array}{c}0.006 * * * \\
{[0.000]}\end{array}$ \\
\hline Constant & $\begin{array}{c}0.060^{* * *} \\
{[0.001]}\end{array}$ & $\begin{array}{c}0.142 * * * \\
{[0.003]}\end{array}$ & $\begin{array}{c}0.123^{* * *} \\
{[0.002]}\end{array}$ & $\begin{array}{c}0.080^{* * *} \\
{[0.002]}\end{array}$ & $\begin{array}{c}0.046 * * * \\
{[0.001]}\end{array}$ & $\begin{array}{c}0.018 * * * \\
{[0.002]}\end{array}$ & $\begin{array}{c}0.043 * * * \\
{[0.001]}\end{array}$ & $\begin{array}{c}0.031 * * * \\
{[0.001]}\end{array}$ \\
\hline R-squared & 0.484 & 0.496 & 0.493 & 0.487 & 0.490 & 0.520 & 0.492 & 0.519 \\
\hline
\end{tabular}

Notes. First stage regression results are shown for the following probit model: $P(\text { Capital Issuance })_{i, t}=\gamma_{0}+\gamma_{1} F P I_{j, t-1}+\gamma_{2} X_{i, t-1}+\gamma_{3} Y_{j, t-1}+\gamma_{4} I_{i}+\gamma_{5} t+\varepsilon$ where FPI is foreign portfolio investment standardized by gross domestic product and represents the instrumented value obtained from the following first stage regression: FPI $I_{j, t}=\beta_{0}+\beta_{1} \Delta F X R a t e_{j, t-1}+\beta_{2}$ Share $_{j, t-1}+\beta_{3}$ RelIntRates $_{j, t-1}+$ $\beta_{4} \mathrm{FPIVol}_{j, t-1}+\varepsilon . \Delta \mathrm{FXRate}$ is the change in the real foreign exchange rate. Share is country j's market capitalization scaled by world market capitalization. RelIntRates is the annual real interest rates of country j scaled by sample average calculated annually. FPIVol is the variance of FPI flows in times t-1 through t-3. Development groups are based on the level of property rights in a nation. Only small firms are tested. Y is a vector of lagged macroeconomic variables including the following: GDP Growth is the average growth rate in gross domestic product of country j. Foreign Direct Inv. is the level of foreign direct investment scaled by country j's GDP. Domestic Credit is the level of credit provided to the public by domestic banks and financial institutions. Savings is the difference between GDP and consumption, scaled by GDP. Investment is the perceived risk facing foreign investors. Law and Order is an index referring to the development of the legal system. Corruption is an index that reflects the level of corruption. X is a vector of lagged firm-specific variables such as cash flow, debt/asset level, risk, profitability, and asset tangibility. I is a vector of industry dummies to control for industry effects and $t$ represents time dummies, which control for any time effects in the panel. Observations are firm year specific and for the term 1996-2005. Firm level control variables are left out for brevity. Robust standard errors clustered around issuer are in brackets. Marginal effects of the variables are provided.

* Significance at the $10 \%$ level.

** Idem, $5 \%$.

*** Idem, $1 \%$. 


\section{References}

Agarwal, R.N., 1997. FPI in Some Developing Countries: A study of determinants and macroeconomic impact, Indian Economic Review 32, 217-229.

Aggarwal, R., L. Klapper, Wysocki, P., 2005. Portfolio preferences of foreign institutional investors, Journal of Banking and Finance 29(12), 2,919-2,946.

Agosin, M., Machado, R., 2005. Foreign investment in developing countries: Does it crowd in domestic investment? Oxford Development Studies 33(2), 149-162.

Asquith, P., Gertner, R., Scharfstein, D., 1994. Anatomy of financial distress: An examination of junkbond issuers, Quarterly Journal of Economics 109(3), 625-658.

Baker, M., Wurgler, J., 2002. Market-timing and capital structure, Journal of Finance 57(1), 1-32.

Barclay, M., Smith Jr., C., 1995. The maturity structure of corporate debt, Journal of Finance 50(2), 609631.

Beck, T., Demirgüç Kunt, A., Levine, R., 2005. Law and firms’ access to finance, American Law and Economics Review 7, 211-252.

Beck, T., Demirgüç-Kunt, A., Laeven, L., Maksimovic, V., 2006. The determinants of financing obstacles, Journal of International Money and Finance 25, 932-52.

Beck, T., Demirgüç-Kunt, A., Maksimovic, V., 2002. Funding growth in bank-based and market-based financial systems: Evidence from firm level data, Journal of Financial Economics 65(3), 337-363.

Bekaert, G., Harvey, C., 2000. Foreign speculators and emerging equity markets, Journal of Finance 55(2), 565-613.

Bekaert, G., Harvey, C., 2003. Emerging market finance, The Journal of Empirical Finance 10, 3-55.

Bekaert, G., Harvey, C., Lundblad, C., 2003. Did financial liberalization spur growth? Journal of Financial Economics 77, 3-55.

Berger, A., Miller, N., Petersen, M., Rajan, R., Stein, J., 2005. Does function follow organizational form? Evidence from the lending practices of large and small banks, Journal of Financial Economics 76(2), 237-269.

Bernanke, B., Blinder, A., 1988. Credit, money and aggregate demand, American Economic Review 78(2), 435-439.

Borensztein, E., Gelos, R.G., 2001. A panic prone pack? The behavior of emerging market mutual funds, IMF Working Paper.

Cai, F., Warnock, F.E., 2004. International diversification at home and abroad, International Finance Discussion Paper.

Claessens, S., Laeven, L., 2003. Financial development, property rights and growth, Journal of Finance 58(6), 2,401-2,436. 
Cull, R., Davis, L., Lamoreaux, N., Rosenthal, J., 2005. Historical financing of SMES, World Bank Group Unpublished Working Paper.

Dahlquist, M., Robertssonb, G., 2001. Direct foreign ownership, institutional investors, and firm characteristics, Journal of Financial Economics, 59(3), 413-440.

De Backer, K., Sleuwaegen, L., 2004. Does foreign direct investment crowd out domestic entrepreneurship? Leuven Gent Management School Unpublished Working Paper.

Demirgüç-Kunt, A., Maksimovic, V., 1998. Law, finance and firm growth, Journal of Finance 53(6), 2,107-2,137.

Desai, M., Foley, C.F., Hines, J., 2004. A multinational perspective on capital structure choice and internal capital markets, Journal of Finance 59(6), 2,451-2,488.

Edison, H., Warnock, F.E., 2004. U.S. investors' emerging market equity portfolios: A security-level analysis, Review of Economics and Statistics 86, 791-804.

Eun, C., Claessens, S., Jun, K., 1995. Pricing externalities in the world financial markets: Theory and policy implications, Pacific-Basin Finance Journal 3, 31-55.

Gambacorta, L., Mistrulli, P.E., 2004. Does bank capital affect lending behavior? Journal of Financial Intermediation 13(4), 436-457.

Giannetti, M., 2007. Financial liberalization and banking crises: The role of capital inflows and lack of transparency, Journal of Financial Intermediation 16(1), 32-63.

Goldstein, I. Razin, A., 2006. An information-based trade-off between foreign direct investment and foreign portfolio investment: Volatility, transparency and welfare, CEPR Discussion Paper No. 3747.

Harrison, A., McMillan, M., Love, I., 2004. Global capital flows and financing constraints, The Journal of Development Economics 75(1), 269-301.

Henry, P., 2000. Do stock market liberalizations cause investment booms? Journal of Financial Economics 58(1-2), 301-334.

IMF Balance of Payments Manual, 1993.

Kang, J.K., Stulz, R., 1997. Why is there a home bias? An analysis of foreign portfolio equity ownership in Japan, Journal of Financial Economics 46, 3-28.

Kashyap, A., Stein, J., 1995. The impact of monetary policy on bank balance sheets, Carnegie-Rochester Conference Series on Public Policy 42, 151-195.

Kashyap, A., Stein, J., 2000. What do a million observations on banks say about the transmission of monetary policy? American Economic Review 90(3), 407-428.

Khurana, I., Martin, X., Pereira, R., 2006. Financial development and the cash flow sensitivity of cash, Journal of Financial and Quantitative Analysis, 41. 
Kim, E.H., Singal, V., 2000. Stock market openings: Experience of emerging economies, Journal of Business 73(1): 25-66.

Korajczyk, R., Levy, A., 2003. Capital structure choice: Macroeconomic conditions and access to finance, Journal of Financial Economics 68(1), 75-109.

Laeven, L., 2003. Does financial liberalization reduce financing constraints? Financial Management 32(1), 5-34.

La Porta, R., Lopez-de-Silanes, F., Shleifer, A., Vishny, R., 1997. Legal determinants of external finance, Journal of Finance 52, 1,131-1,150.

La Porta, R., Lopez-de-Silanes, F., Shleifer, A., 2006. What works in securities laws? Journal of Finance 61(1), 1-31.

Leary, M., Roberts, M., 2005. Do firms rebalance their capital structures? Journal of Finance 60(6), 2575-2619.

Leuz, C., Lins, K., Warnock, F., 2008. Do foreigners invest less in poorly governed firms? Review of Financial Studies, forthcoming.

Lins, K., Strickland, D., Zenner, M., 2005. Do non-U.S. firms issue stock on U.S. equity markets to relax capital constraints? Journal of Financial and Quantitative Analysis 40(1), 109-133.

Miller, D., Puthenpurackal, J., 2002. The costs, wealth effects, and determinants of international capital raising: Evidence from public yankee bonds, Journal of Financial Intermediation 11(4), 455-485.

Mukherjee, P., Bose, S., Coondoo, D., 2002. Foreign institutional investment in the Indian equity market: An analysis of daily flows during January 1999-May 2002, Money \& Finance, 2(9-10).

Patro, D., Wald, J., 2005. Firm characteristics and the impact of emerging market liberalization, Journal of Banking and Finance 29(7), 1,671-1,695.

Peek, J., Rosengren, E., 1995. Bank regulation and the credit crunch, Journal of Banking \& Finance 19(34), 679-692.

Rajan, R., Zingales, L., 1995. What do we know about capital structure? Some evidence from international data, Journal of Finance 50(5), 1,421-1,460.

Rajan, R., Zingales, L., 1998. Financial dependence and growth, American Economic Review 88(3), 559586.

Samak, N., Helmy, O., 2000. Foreign portfolio equity investment in Egypt: An analytical overview, Cairo University Unpublished Working Paper.

Titman, S., Wessels, R., 1988. The determinants of capital structure choice, Journal of Finance 43(1), 119.

Wurgler, J., 2000. Financial markets and the allocation of capital. Journal of Financial Economics 58, 187-214. 


\section{Footnotes}

${ }^{1}$ See also Kim and Singal (2000), who find that liberalization improves returns and Bekaert and Harvey (2000), who find that liberalization decreases the cost of capital. Both of these could have positive externalities with regard to small firm access to capital.

${ }^{2}$ Alternatively, an increase in asset values of purely domestic firms based on the cross-listing of international firms may improve access to finance for these firms (i.e., small listed firms). Eun, Claessens, and Jun (1995) show theoretically that this positive asset-pricing spill-over effect might occur when markets become partially integrated. According to Miller and Puthenpurackal (2002), however, this effect would be mostly felt in countries where property rights were protected. For this reason, I do not use this as a theoretical basis.

${ }^{3}$ Small is defined here as listed firms that have total assets less than the country-year median. This paper does not attempt to empirically examine private firms. Number of employees is not used due to lack of data and resultant sample selection problems. ${ }^{4}$ See also Khurana, Martin, and Pereira (2006) who do an analogous examination to Harrison, McMillan, and Love (2004) looking at financial development and cash flow sensitivity.

${ }^{5}$ See Goldstein and Razin (2006) for a theoretical motivation of the choice between foreign direct investment and foreign portfolio investment.

${ }^{6}$ Foreign direct investment is defined by the IMF as investment that is concerned with longer-term ownership (contrasted with foreign portfolio investment, which is often considered short-term) or a controlling interest of more than $10 \%$ (Balance of Payments, 1993).

${ }^{7}$ According to Beck et al. 2003, small firms are financially constrained so often that small is a good proxy for financial constraint. Because this is the case, one can assume that whether a firm issues capital or not is indicative of whether they can access markets.

${ }^{8}$ Results are robust to using three-year trailing averages for all macroeconomic variables. These results were included in a previous version of the paper and are available upon request.

${ }^{9} \mathrm{~N}=50$ is used for bootstrap replication; both stages of the regression are performed for each draw.

${ }^{10}$ Demirgüç-Kunt and Maksimovic (1998) also use this methodology.

${ }^{11}$ I assume this is $100 \%$ to be conservative. This assumption would tend to bias results toward a rejection of the hypothesis.

${ }^{12}$ Rajan and Zingales (1998) examine inter-country differences between industries based on both macro and firm-specific information.

13 This results in 52,276 observations being dropped.

${ }^{14} \mathrm{I}$ am not able to observe the impact of FPI on trade credit. This is an unfortunate limitation of the data.

${ }^{15}$ Global new issues are not consistently available preceding 1996 in SDC.

${ }^{16}$ Issuances include IPOs. The sample is not limited to those that were public on 1/1/1996.

${ }^{17}$ These countries are Costa Rica, Czech Republic, Iceland, Luxembourg, Papua New Guinea, South Africa, and Bangladesh.

${ }^{18}$ The analyses are also done using average size of the eight-year period. As results persist, they are omitted for brevity.

${ }^{19}$ All forms of cross-listing are treated the same here (e.g., Level I, II, or III ADR programs, private placement (Rule 144A) or Canadian direct listing.

${ }^{20}$ This number is obtained by multiplying the coefficient in Specification 1 of Table 4 by the standard deviation of FPI (scaled by GDP), which is found, rounded to the nearest hundredth, in Table 2.

${ }^{21}$ South Korea was liberalized in 1998, two years after the first year of the examination period. Chile initiated the encaje, which is legislation that might have had an impact on FPI levels, and Hong Kong did not have FPI levels for part of the sample period. 
Table 1. Security Issuances and Investment Environment

\begin{tabular}{|c|c|c|c|c|c|c|c|}
\hline Country & Debt Issues & $\begin{array}{l}\text { Equity } \\
\text { Issues }\end{array}$ & Total Issues & $\begin{array}{l}\text { Avg Annual } \\
\text { Proceeds }\end{array}$ & $\begin{array}{c}\text { Foreign } \\
\text { Portfolio } \\
\text { Investment }\end{array}$ & $\begin{array}{c}\text { Gross } \\
\text { Domestic } \\
\text { Product }\end{array}$ & $\begin{array}{c}\text { Property } \\
\text { Rights }\end{array}$ \\
\hline \multicolumn{8}{|c|}{ Panel A: Developed Property Rights Nations } \\
\hline Austria & 6 & 63 & 69 & 102.85 & $2.00 \mathrm{E}+09$ & $2.10 \mathrm{E}+11$ & 1 \\
\hline Belgium & 35 & 90 & 125 & 112.11 & $-1.58 \mathrm{E}+11$ & $2.49 \mathrm{E}+11$ & 1 \\
\hline Canada & 323 & 2,280 & 2,603 & 46.96 & $-5.49 E+09$ & $6.78 \mathrm{E}+11$ & 1 \\
\hline Chile & 69 & 115 & 184 & 60.97 & $-7.88 \mathrm{E}+08$ & $7.08 \mathrm{E}+10$ & 1 \\
\hline Denmark & 6 & 116 & 122 & 72.02 & $-3.23 E+09$ & $1.72 \mathrm{E}+11$ & 1 \\
\hline Finland & 12 & 122 & 134 & 150.94 & $-2.45 E+09$ & $1.28 \mathrm{E}+11$ & 1 \\
\hline Germany & 60 & 578 & 638 & 270.76 & $1.05 \mathrm{E}+09$ & $2.11 \mathrm{E}+12$ & 1 \\
\hline Hong Kong & 58 & 1,222 & 1,280 & 36.40 & $-9.27 E+09$ & $1.61 \mathrm{E}+11$ & 1 \\
\hline Ireland & 4 & 74 & 78 & 136.73 & $-1.36 \mathrm{E}+10$ & $9.42 \mathrm{E}+10$ & 1 \\
\hline Netherlands & 27 & 182 & 209 & 330.58 & $-9.71 E+09$ & $4.00 \mathrm{E}+11$ & 1 \\
\hline New Zealand & 21 & 91 & 112 & 55.06 & $-6.26 \mathrm{E}+07$ & $6.06 \mathrm{E}+10$ & 1 \\
\hline Norway & 12 & 150 & 162 & 64.58 & $-1.15 E+10$ & $1.65 E+11$ & 1 \\
\hline Singapore & 144 & 510 & 654 & 42.18 & $-1.09 \mathrm{E}+10$ & $8.77 \mathrm{E}+10$ & 1 \\
\hline United Kingdom & 99 & 2,839 & 2,938 & 77.12 & $4.15 \mathrm{E}+10$ & $1.43 \mathrm{E}+12$ & 1 \\
\hline United States & 2,238 & 5,617 & 7,855 & 178.66 & $2.16 \mathrm{E}+11$ & $8.99 E+12$ & 1 \\
\hline Switzerland & 95 & 122 & 217 & 228.34 & $-2.03 E+10$ & $2.72 E+11$ & 1.125 \\
\hline Japan & 1,743 & 3,127 & 4,870 & 81.77 & $-4.50 \mathrm{E}+10$ & $4.40 \mathrm{E}+12$ & 1.25 \\
\hline Sweden & 18 & 315 & 333 & 111.51 & $-1.40 \mathrm{E}+10$ & $2.47 \mathrm{E}+11$ & 1.625 \\
\hline Thailand & 122 & 242 & 364 & 39.26 & $7.73 \mathrm{E}+08$ & $1.35 E+11$ & 1.75 \\
\hline France & 68 & 750 & 818 & 169.94 & $-9.87 E+09$ & $1.44 \mathrm{E}+12$ & 2 \\
\hline Hungary & 0 & 12 & 12 & 152.63 & $9.01 \mathrm{E}+08$ & $4.96 \mathrm{E}+10$ & 2 \\
\hline Israel & 1 & 84 & 85 & 59.93 & $1.02 \mathrm{E}+09$ & $1.06 \mathrm{E}+11$ & 2 \\
\hline Italy & 14 & 191 & 205 & 288.33 & $5.19 \mathrm{E}+09$ & $1.17 \mathrm{E}+12$ & 2 \\
\hline Poland & 2 & 49 & 51 & 54.93 & $1.62 \mathrm{E}+09$ & $1.71 \mathrm{E}+11$ & 2 \\
\hline Portugal & 18 & 55 & 73 & 203.04 & $4.33 \mathrm{E}+08$ & $1.12 \mathrm{E}+11$ & 2 \\
\hline Spain & 32 & 120 & 152 & 286.68 & $-6.09 E+09$ & $6.03 \mathrm{E}+11$ & 2 \\
\hline \multicolumn{8}{|c|}{ Panel B: Hybrid Nations (classification dependent on annual rating) } \\
\hline Greece & 4 & 184 & 188 & 77.27 & $5.24 \mathrm{E}+09$ & $1.23 \mathrm{E}+11$ & 2.25 \\
\hline Turkey & 0 & 20 & 20 & 146.93 & $-6.09 E+08$ & $1.83 \mathrm{E}+11$ & 2.25 \\
\hline Malaysia & 106 & 648 & 754 & 36.32 & $-6.01 \mathrm{E}+08$ & $9.10 \mathrm{E}+10$ & 2.375 \\
\hline Philippines & 18 & 46 & 64 & 55.47 & $1.17 \mathrm{E}+09$ & $7.58 \mathrm{E}+10$ & 2.375 \\
\hline Argentina & 79 & 60 & 139 & 90.66 & $-5.19 E+08$ & $2.51 \mathrm{E}+11$ & 2.5 \\
\hline Venezuela & 28 & 28 & 56 & 53.70 & $-2.35 \mathrm{E}+08$ & $1.00 \mathrm{E}+11$ & 2.5 \\
\hline Sri Lanka & 0 & 13 & 13 & 11.23 & $-6,994,878$ & $1.55 \mathrm{E}+10$ & 2.875 \\
\hline \multicolumn{8}{|c|}{ Panel C: Less Developed Property Rights Nations } \\
\hline Brazil & 241 & 36 & 277 & 112.32 & $5.86 \mathrm{E}+09$ & $6.01 \mathrm{E}+11$ & 3 \\
\hline India & 166 & 1,062 & 1,228 & 9.93 & $2.70 \mathrm{E}+09$ & $4.54 \mathrm{E}+11$ & 3 \\
\hline Mexico & 149 & 58 & 207 & 96.87 & $3.77 \mathrm{E}+09$ & $5.00 \mathrm{E}+11$ & 3 \\
\hline Bolivia & 23 & 17 & 40 & 5.63 & $-2.90 \mathrm{E}+07$ & $8.18 \mathrm{E}+09$ & 3.125 \\
\hline Peru & 58 & 6 & 64 & 17.14 & $5.00 \mathrm{E}+08$ & $5.50 \mathrm{E}+10$ & 3.125 \\
\hline Colombia & 64 & 24 & 88 & 13.58 & $6.61 \mathrm{E}+08$ & $9.08 \mathrm{E}+10$ & 3.25 \\
\hline Indonesia & 85 & 158 & 243 & 60.63 & $1.60 \mathrm{E}+08$ & $1.68 \mathrm{E}+11$ & 3.375 \\
\hline Pakistan & 0 & 17 & 17 & 6.49 & $-3.06 E+07$ & $6.67 E+10$ & 3.375 \\
\hline China & 34 & 905 & 939 & 76.86 & $-5.21 E+09$ & $1.10 \mathrm{E}+12$ & 4 \\
\hline South Korea & 3,141 & 882 & 4,023 & 24.96 & $9.24 \mathrm{E}+09$ & $5.03 E+11$ & \\
\hline Total & 9,423 & 23,280 & 32,703 & & & & \\
\hline
\end{tabular}


Table 2. Summary Statistics from 1996-2005

\begin{tabular}{|c|c|c|c|c|c|}
\hline \multicolumn{6}{|c|}{ Panel A: Firm-Level Variables } \\
\hline Variable & Obs. & Mean & Std. Dev. & Min & Max \\
\hline \multicolumn{6}{|c|}{ Small Firms } \\
\hline Capital Dummy & 67,731 & 0.10 & 0.30 & 0.00 & 1.00 \\
\hline Asset Tangibility & 67,355 & 0.59 & 0.37 & 0.56 & 1.41 \\
\hline Cash & 67,355 & 0.16 & 0.17 & 0.00 & 0.64 \\
\hline Cross-listing & 67,355 & 0.01 & 0.11 & 0.00 & 1.00 \\
\hline Short-term Leverage & 63,553 & 0.43 & 19.42 & 0.00 & 4896 \\
\hline Long-term Leverage & 64,608 & 0.11 & 0.13 & 0.00 & 5.81 \\
\hline Total Leverage & 67,355 & 0.53 & 0.27 & 0.05 & 1.12 \\
\hline Profitability & 67,355 & -0.07 & 0.42 & -1.46 & 0.47 \\
\hline$\underline{\text { Risk }}$ & 67,355 & 0.08 & 0.09 & 0.00 & 0.49 \\
\hline \multicolumn{6}{|c|}{ Large Firms } \\
\hline Capital Dummy & 51,144 & 0.17 & 0.38 & 0.00 & 1.00 \\
\hline Asset Tangibility & 51,144 & 0.52 & 0.25 & 0.09 & 1.08 \\
\hline Cash & 51,144 & 0.10 & 0.11 & 0.00 & 0.45 \\
\hline Cross-listing & 51,144 & 0.09 & 0.28 & 0.00 & 1.00 \\
\hline Short-term Leverage & 49,593 & 0.35 & 0.21 & 0.00 & 8.00 \\
\hline Long-term Leverage & 45,418 & 0.16 & 0.15 & 0.00 & 1.92 \\
\hline Total Leverage & 51,144 & 0.55 & 0.23 & 0.11 & 0.96 \\
\hline Profitability & 51,144 & 0.02 & 0.20 & -0.59 & 0.36 \\
\hline Risk & 51,144 & 0.05 & 0.06 & 0.00 & 0.37 \\
\hline \multicolumn{6}{|c|}{ Panel B: Country-Level Variables } \\
\hline Corruption & 345 & 3.75 & 1.37 & 1.00 & 6.00 \\
\hline Domestic Credit & 348 & 0.96 & 0.55 & 0.10 & 3.22 \\
\hline Foreign Direct Inv. & 348 & 0.04 & 0.07 & -0.03 & 0.94 \\
\hline Fiscal Burden & 312 & 3.63 & 0.91 & 1.00 & 5.00 \\
\hline FPI & 348 & -0.01 & 0.05 & -0.30 & 0.15 \\
\hline FPIVol & 348 & 0.12 & 0.46 & 0.00 & 6.26 \\
\hline$\Delta$ FXRate & 348 & 0.06 & 0.15 & -0.24 & 1.24 \\
\hline GDP Growth & 348 & 0.03 & 0.03 & -0.13 & 0.11 \\
\hline Investment & 345 & 8.32 & 2.09 & 3.00 & 12.00 \\
\hline Law and Order & 345 & 4.79 & 1.34 & 1.00 & 6.00 \\
\hline Real Interest Rates & 348 & 0.07 & 0.10 & -0.35 & 0.78 \\
\hline Relative Interest Rates & 348 & 0.01 & 0.02 & -0.06 & 0.12 \\
\hline Savings & 348 & 0.24 & 0.09 & -0.05 & 0.53 \\
\hline Share & 348 & 0.73 & 0.66 & 0.03 & 4.18 \\
\hline
\end{tabular}

Notes. Asset tangibility is defined as fixed assets divided by the book value of total assets. Cash is defined as cash and/or marketable securities scaled by total assets. Cross-listing is a dummy variable which takes on a value of one if a firm is cross-listed and zero otherwise. Growth in sales/ total assets is defined as the log difference in sales/total assets of firm i. Leverage is total liabilities scaled by total assets. Profitability is defined as operating income divided by sales. Risk is defined as the standard deviation of the firm's profitability ratio over the previous three years. Corruption is an assigned value for a given country regarding its level of corruption ( 0 most corrupt; 6 least corrupt). Dom Credit refers to credit provided by financial institutions scaled by GDP. Domestic Credit (banks) refers to credit provided by all banks scaled by GDP. Foreign Direct Inv. is the amount of foreign direct investment scaled by GDP. Fiscal Burden is the level of taxation a country imposes on its firms. FPI is the investment (in dollars) in the equity of foreign companies. FPI Vol is the variance of FPI net flows from time t- 3 through t- $1 . \Delta \mathrm{FX}$ Rate is the log difference in the official exchange rate with the dollar. GDP Growth is the growth rate of gross domestic product. Invest is an index of the risk involved in investing in a country. Law and Order is an index that refers to the level of legal development. Property Rights is a measure from 1 (most effective) to 5 (least effective) measuring the efficacy of a country's legal system. Real Interest Rates are interest rates adjusted for inflation levels. Relative Interest Rates are the annual real interest rates of country j scaled by sample average calculated annually. Share is the percent of the world market capitalization represented by a country's market capitalization.

* Significance at the $10 \%$ level.

** Idem, $5 \%$.

*** Idem, $1 \%$. 
Table 3. Correlation (Small Firm Sample)

\begin{tabular}{|c|c|c|c|c|c|c|c|c|c|c|c|c|c|}
\hline \multicolumn{8}{|c|}{ Panel A: Firm-Level Variable Correlation } & & & & & & \\
\hline & 1 & 2 & 3 & 4 & 5 & 6 & 7 & & & & & & \\
\hline Asset Tangibility (1) & 1.00 & & & & & & & & & & & & \\
\hline Cash (2) & -0.41 & 1.00 & & & & & & & & & & & \\
\hline Cross-listing (3) & -0.04 & 0.05 & 1.00 & & & & & & & & & & \\
\hline Short-term Leverage (4) & -0.31 & -0.06 & -0.03 & 1.00 & & & & & & & & & \\
\hline Long-term Leverage (5) & 0.35 & -0.24 & -0.01 & -0.19 & 1.00 & & & & & & & & \\
\hline Total Leverage (6) & 0.09 & -0.18 & -0.06 & 0.10 & 0.21 & 1.00 & & & & & & & \\
\hline Profitability (7) & 0.13 & -0.18 & -0.06 & -0.07 & 0.12 & 0.09 & 1.00 & & & & & & \\
\hline Risk (8) & -0.10 & 0.12 & $\mathbf{0 . 0 7}$ & -0.01 & -0.08 & -0.17 & -0.21 & & & & & & \\
\hline \multicolumn{14}{|c|}{ Panel B: Country-Level Variable Correlation } \\
\hline & 1 & 2 & 3 & 4 & 5 & 6 & 7 & 8 & 9 & 10 & 11 & 12 & 13 \\
\hline GDP Growth (1) & 1.00 & & & & & & & & & & & & \\
\hline Savings (2) & 0.22 & 1.00 & & & & & & & & & & & \\
\hline Domestic Credit (3) & -0.06 & 0.22 & 1.00 & & & & & & & & & & \\
\hline Foreign Direct Inv. (4) & 0.10 & 0.20 & 0.07 & 1.00 & & & & & & & & & \\
\hline Share (5) & 0.06 & 0.29 & 0.45 & 0.22 & 1.00 & & & & & & & & \\
\hline Corruption (6) & 0.01 & 0.04 & 0.23 & 0.07 & 0.33 & 1.00 & & & & & & & \\
\hline Investment (7) & 0.01 & -0.02 & 0.27 & 0.16 & 0.24 & 0.24 & 1.00 & & & & & & \\
\hline Law and Order (8) & 0.09 & 0.25 & 0.46 & 0.15 & 0.35 & 0.68 & 0.26 & 1.00 & & & & & \\
\hline FPIVol (9) & -0.03 & 0.09 & 0.08 & 0.16 & 0.39 & 0.07 & 0.15 & 0.08 & 1.00 & & & & \\
\hline Real Interest Rates (10) & -0.07 & -0.20 & -0.15 & -0.01 & -0.12 & -0.09 & -0.12 & -0.26 & -0.03 & 1.00 & & & \\
\hline Fiscal Burden (11) & -0.06 & -0.29 & 0.13 & -0.05 & -0.10 & 0.46 & 0.29 & 0.39 & -0.09 & -0.11 & 1.00 & & \\
\hline Relative Int. Rates (12) & -0.07 & -0.19 & -0.15 & -0.02 & -0.12 & -0.10 & -0.11 & -0.26 & -0.01 & 0.98 & -0.12 & 1.00 & \\
\hline FXChg (13) & -0.34 & -0.02 & -0.24 & -0.01 & -0.15 & -0.24 & -0.33 & -0.30 & -0.05 & -0.06 & -0.14 & -0.06 & 1.00 \\
\hline FPI (14) & 0.00 & -0.37 & -0.10 & -0.21 & -0.29 & -0.11 & -0.18 & -0.19 & -0.35 & 0.12 & 0.04 & 0.11 & 0.01 \\
\hline
\end{tabular}

Bold font identifies significance of $5 \%$. 
Table 4. FPI and Small Firm Access to Capital

\begin{tabular}{|c|c|c|c|c|c|c|c|c|}
\hline \multicolumn{9}{|c|}{ Dependent Variable: Capital Issuance Dummy } \\
\hline & \multicolumn{4}{|c|}{ Developed Property Rights (N=57,247) } & \multicolumn{4}{|c|}{ Less Developed Property Rights $(\mathrm{N}=9,169)$} \\
\hline & 1 & 2 & 3 & 4 & 5 & 6 & 7 & 8 \\
\hline \multirow[t]{2}{*}{ FPI } & $0.338 * * *$ & $0.307 * * *$ & $0.339 * * *$ & $0.316^{* * *}$ & $3.390 * * *$ & $4.266^{* * *}$ & $3.060 * * *$ & $2.900 * * *$ \\
\hline & [0.087] & {$[0.069]$} & [0.068] & {$[0.081]$} & {$[0.553]$} & {$[0.579]$} & [0.561] & {$[0.384]$} \\
\hline \multirow[t]{2}{*}{ Foreign Direct Inv. } & 0.003 & 0.017 & $0.095^{*}$ & 0.004 & $0.591 * * *$ & $0.958 * * *$ & $0.641 * * *$ & $0.797 * * *$ \\
\hline & [0.055] & {$[0.066]$} & {$[0.056]$} & [0.046] & [0.192] & {$[0.148]$} & {$[0.151]$} & {$[0.137]$} \\
\hline \multirow[t]{2}{*}{ GDP Growth } & $1.304^{* * *}$ & $1.350 * * *$ & $1.158 * * *$ & $1.296 * * *$ & -0.070 & -0.115 & -0.095 & $-0.195 * *$ \\
\hline & {$[0.213]$} & [0.217] & {$[0.219]$} & [0.214] & {$[0.106]$} & {$[0.080]$} & {$[0.111]$} & [0.079] \\
\hline \multirow[t]{2}{*}{ Domestic Credit } & $0.011^{*}$ & $0.011^{*}$ & $0.015^{* *}$ & $0.010^{*}$ & $-0.127 * * *$ & $-0.128 * * *$ & $-0.118 * * *$ & $-0.114^{* * *}$ \\
\hline & {$[0.006]$} & {$[0.006]$} & {$[0.007]$} & [0.005] & [0.025] & {$[0.022]$} & {$[0.026]$} & {$[0.024]$} \\
\hline \multirow[t]{2}{*}{ Savings } & -0.022 & -0.06 & -0.083 & -0.036 & $0.729 * * *$ & $0.762 * * *$ & $0.656 * * *$ & $0.605^{* * *}$ \\
\hline & [0.079] & {$[0.084]$} & {$[0.085]$} & {$[0.078]$} & [0.126] & {$[0.116]$} & [0.139] & {$[0.102]$} \\
\hline \multirow[t]{2}{*}{ Investment } & & -0.004 & & & & $-0.013^{* * *}$ & & \\
\hline & & {$[0.003]$} & & & & [0.002] & & \\
\hline \multirow[t]{2}{*}{ Law and Order } & & & $-0.023^{* * *}$ & & & & 0.002 & \\
\hline & & & [0.004] & & & & {$[0.004]$} & \\
\hline \multirow[t]{2}{*}{ Corruption } & & & & -0.002 & & & & $-0.021 * * *$ \\
\hline & & & & [0.002] & & & & [0.004] \\
\hline Industry Dummies & Yes & Yes & Yes & Yes & Yes & Yes & Yes & Yes \\
\hline Time Dummies & Yes & Yes & Yes & Yes & Yes & Yes & Yes & Yes \\
\hline R-squared (1 $1^{\text {st }}$ stage $)$ & 0.439 & 0.496 & 0.494 & 0.487 & 0.490 & 0.520 & 0.492 & 0.519 \\
\hline F-Test (instruments) & $0.000 * * *$ & $0.000 * * *$ & $0.000 * * *$ & $0.000 * * *$ & $0.000 * * *$ & $0.000 * * *$ & $0.000 * * *$ & $0.000 * * *$ \\
\hline Model $\chi^{2}$ & $8,406 * * *$ & $8,413 * * *$ & $8,484 * * *$ & $8,407 * * *$ & $978 * * *$ & $983 * * *$ & $978 * * *$ & $999 * * *$ \\
\hline \multicolumn{9}{|c|}{ 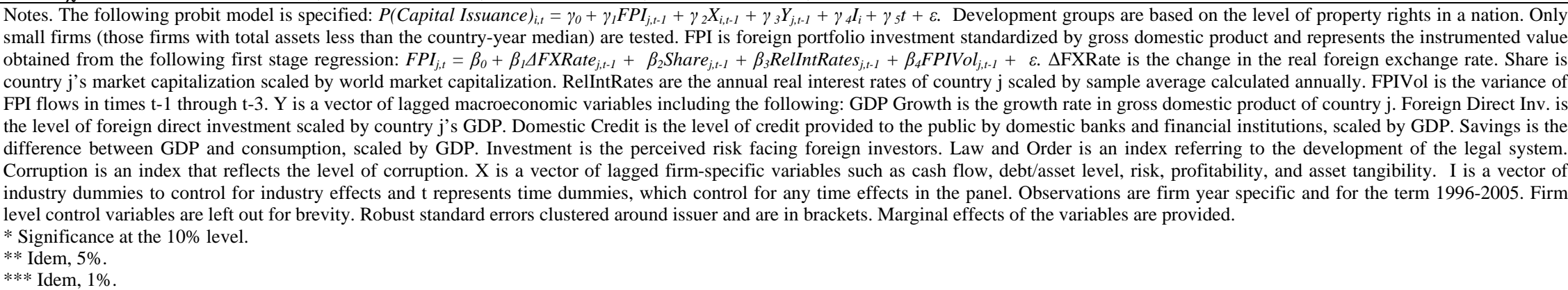 } \\
\hline
\end{tabular}


Table 5. FPI and Large Firm Access to Capital

Dependent Variable: Capital Issuance Dummy

\begin{tabular}{|c|c|c|c|c|c|c|c|c|}
\hline \multicolumn{9}{|c|}{ Dependent Variable: Capital Issuance Dummy } \\
\hline & \multicolumn{4}{|c|}{ Developed Property Rights $(\mathrm{N}=44,058)$} & \multicolumn{4}{|c|}{ Less Developed Property Rights $(\mathrm{N}=6,772)$} \\
\hline & 1 & 2 & 3 & 4 & 5 & 6 & 7 & 8 \\
\hline \multirow[t]{2}{*}{ FPI } & $-0.278 * *$ & -0.132 & $-0.164^{*}$ & -0.139 & $-10.584 * * *$ & $-6.597 * *$ & $-9.295 * * *$ & $-3.835 * * *$ \\
\hline & {$[0.111]$} & [0.098] & [0.092] & [0.105] & [3.115] & {$[2.972]$} & [2.988] & {$[0.968]$} \\
\hline \multirow[t]{2}{*}{ Foreign Direct Inv. } & $-0.140 * * *$ & $-0.142 * * *$ & $-0.185^{* * *}$ & $-0.159 * * *$ & $0.860 * * *$ & 0.145 & $0.784 * * *$ & 0.159 \\
\hline & {$[0.052]$} & [0.049] & {$[0.050]$} & {$[0.050]$} & [0.289] & {$[0.272]$} & [0.302] & {$[0.181]$} \\
\hline \multirow[t]{2}{*}{ GDP Growth } & $0.814^{* * *}$ & $0.742 * * *$ & $0.861 * * *$ & $0.795 * * *$ & $0.886 * * *$ & 0.420 & $0.813^{* * *}$ & $0.488 * * *$ \\
\hline & [0.109] & [0.087] & [0.115] & {$[0.070]$} & [0.322] & {$[0.260]$} & {$[0.244]$} & {$[0.160]$} \\
\hline \multirow[t]{2}{*}{ Domestic Credit } & $0.014 * * *$ & $0.015 * * *$ & $0.010^{* *}$ & $0.020 * * *$ & $0.322 * * *$ & 0.119 & $0.272^{* *}$ & $0.064 *$ \\
\hline & {$[0.003]$} & [0.003] & {$[0.004]$} & {$[0.003]$} & {$[0.120]$} & [0.089] & [0.118] & {$[0.036]$} \\
\hline \multirow[t]{2}{*}{ Savings } & $-0.210 * * *$ & $-0.128 * *$ & $-0.116^{* *}$ & $-0.101 * *$ & $-1.810 * * *$ & -0.678 & $-1.499 * *$ & -0.239 \\
\hline & [0.056] & [0.057] & {$[0.052]$} & [0.051] & {$[0.695]$} & [0.542] & {$[0.695]$} & {$[0.160]$} \\
\hline Investment & & $\begin{array}{c}0.006 * * * \\
{[0.002]}\end{array}$ & & & & $\begin{array}{l}0.020 * \\
{[0.010]}\end{array}$ & & \\
\hline \multirow{2}{*}{ Law and Order } & & & $0.021 * * *$ & & & & -0.005 & \\
\hline & & & [0.004] & & & & {$[0.006]$} & \\
\hline Corruption & & & & $0.016 * * *$ & & & & $0.038 * * *$ \\
\hline & & & & [0.002] & & & & {$[0.008]$} \\
\hline Industry Dummies & Yes & Yes & Yes & Yes & Yes & Yes & Yes & Yes \\
\hline Time Dummies & Yes & Yes & Yes & Yes & Yes & Yes & Yes & Yes \\
\hline R-squared (1 $1^{\text {st }}$ stage) & 0.326 & 0.330 & 0.340 & 0.330 & 0.418 & 0.443 & 0.426 & 0.431 \\
\hline F-Test (instruments) & $0.000^{* * *}$ & $0.000 * * *$ & $0.000^{* * *}$ & $0.000 * * *$ & $0.000 * * *$ & $0.000 * * *$ & $0.000 * * *$ & $0.000 * * *$ \\
\hline Model $\chi^{2}$ & $3,851 * * *$ & $3,899 * * *$ & $3,859 * * *$ & $3,875 * * *$ & $1,443 * * *$ & $1,445 * * *$ & $1,455 * * *$ & $1,446 * * *$ \\
\hline
\end{tabular}

Notes. The following probit model is specified: $P$ (Capital Issuance) $)_{i t}=\gamma_{0}+\gamma_{1} F P I_{j t-1}+\gamma_{2} X_{i t-1}+\gamma_{3} Y_{j+1-1}+\gamma_{4} I_{i}+\gamma_{5} t+\varepsilon$. Development groups are based on the level of property rights in a nation. Only large firms (those firms with total assets greater than the country-year median) are tested. FPI is foreign portfolio investment standardized by gross domestic product and represents the instrumented value obtained from the following first stage regression: $F P I_{j, t}=\beta_{0}+\beta_{1} \Delta F X$ Rate $_{j, t-1}+\beta_{2}$ Share $_{j, t-1}+\beta_{3}$ RelIntRates $_{j, t-1}+\beta_{4}$ FPIVol $_{j, t-1}+\varepsilon . \Delta \mathrm{FXRate}$ is the change in the real foreign exchange rate. Share is country j's market capitalization scaled by world market capitalization. RelIntRates are the annual real interest rates of country $\mathrm{j}$ scaled by sample average calculated annually. FPIVol is the variance of FPI flows in times t-1 through t-3. Y is a vector of lagged macroeconomic variables including the following: GDP Growth is the growth rate in gross domestic product of country j. Foreign Direct Inv. is the level of foreign direct investment scaled by country j’s GDP. Domestic Credit is the level of credit provided to the public by domestic banks and financial institutions, scaled by GDP. Savings is the difference between GDP and consumption, scaled by GDP. Investment is the perceived risk facing foreign investors. Law and Order is an index referring to the development of the legal system. Corruption is an index that reflects the level of corruption. X is a vector of lagged firm-specific variables such as cash flow, debt/asset level, risk, profitability, and asset tangibility. I is a vector of industry dummies to control for industry effects and t represents time dummies, which control for any time effects in the panel. Observations are firm year specific and for the term 1996-2005. Firm level control variables are left out for brevity. Robust standard errors clustered around issuer and are in brackets. Marginal effects of the variables are provided.

* Significance at the $10 \%$ level.

** Idem, $5 \%$.

*** Idem, $1 \%$. 


\section{Table 6. FPI and Small Firm Access to Bank Credit}

Dependent Variable: Capital Issuance Dummy

\begin{tabular}{|c|c|c|c|c|c|c|c|c|c|c|c|c|}
\hline \multirow{3}{*}{ Dependent Variable } & \multicolumn{6}{|c|}{ Developed Property Rights $(\mathrm{N}=57,247)$} & \multirow{2}{*}{\multicolumn{2}{|c|}{$\begin{array}{c}\text { Short-term } \\
\text { Leverage }\end{array}$}} & \multirow{2}{*}{\multicolumn{2}{|c|}{$\begin{array}{c}\text { Long-Term } \\
\text { Leverage }\end{array}$}} & \multirow{2}{*}{\multicolumn{2}{|c|}{$\begin{array}{c}\text { Total } \\
\text { Leverage }\end{array}$}} \\
\hline & \multicolumn{2}{|c|}{$\begin{array}{c}\text { Short-term } \\
\text { Leverage }\end{array}$} & \multicolumn{2}{|c|}{$\begin{array}{c}\text { Long-Term } \\
\text { Leverage }\end{array}$} & \multicolumn{2}{|c|}{$\begin{array}{c}\text { Total } \\
\text { Leverage }\end{array}$} & & & & & & \\
\hline & OLS & Tobit & OLS & Tobit & OLS & Tobit & OLS & Tobit & OLS & Tobit & OLS & Tobit \\
\hline & 1 & 2 & 3 & 4 & 5 & 6 & 7 & 8 & 9 & 10 & 11 & 12 \\
\hline FPI & $\begin{array}{c}4.849 \\
{[4.802]}\end{array}$ & $\begin{array}{c}0.05 \\
{[0.053]}\end{array}$ & $\begin{array}{c}0.134 * * * \\
{[0.032]}\end{array}$ & $\begin{array}{c}0.203^{* * *} \\
{[0.028]}\end{array}$ & $\begin{array}{c}0.312^{* * *} \\
{[0.103]}\end{array}$ & $\begin{array}{c}0.257 * * * \\
{[0.061]}\end{array}$ & $\begin{array}{c}-2.561 * * * \\
{[0.560]}\end{array}$ & $\begin{array}{c}-2.879 * * * \\
{[0.717]}\end{array}$ & $\begin{array}{c}-1.566^{* * *} \\
{[0.413]}\end{array}$ & $\begin{array}{c}-1.638^{* * *} \\
{[0.473]}\end{array}$ & $\begin{array}{c}-4.472 * * * \\
{[0.659]}\end{array}$ & $\begin{array}{c}-4.986^{* * * *} \\
{[0.817]}\end{array}$ \\
\hline Fiscal Burden & $\begin{array}{c}-0.164 \\
{[0.184]}\end{array}$ & $\begin{array}{c}-0.006 * * * \\
{[0.002]}\end{array}$ & $\begin{array}{c}-0.004^{* *} \\
{[0.002]}\end{array}$ & $\begin{array}{c}-0.005^{* * *} \\
{[0.001]}\end{array}$ & $\begin{array}{c}0.036^{* * *} \\
{[0.006]}\end{array}$ & $\begin{array}{c}0.016^{* * *} \\
{[0.002]}\end{array}$ & $\begin{array}{c}0.006 \\
{[0.005]}\end{array}$ & $\begin{array}{c}0.006 \\
{[0.005]}\end{array}$ & $\begin{array}{c}0.016^{* * *} \\
{[0.004]}\end{array}$ & $\begin{array}{c}0.021 * * * \\
{[0.003]}\end{array}$ & $\begin{array}{c}0.010 \\
{[0.007]}\end{array}$ & $\begin{array}{l}0.001^{* *} \\
{[0.006]}\end{array}$ \\
\hline Domestic Credit & $\begin{array}{c}-0.011 \\
{[0.037]}\end{array}$ & $\begin{array}{c}0.026^{* * *} \\
{[0.002]}\end{array}$ & $\begin{array}{c}0.006^{* * *} \\
{[0.002]}\end{array}$ & $\begin{array}{c}0.011^{* * *} \\
{[0.001]}\end{array}$ & $\begin{array}{c}0.039 * * * \\
{[0.005]}\end{array}$ & $\begin{array}{c}0.004 * * * \\
{[0.002]}\end{array}$ & $\begin{array}{c}0.101^{* * *} \\
{[0.024]}\end{array}$ & $\begin{array}{c}0.029 * * * \\
{[0.029]}\end{array}$ & $\begin{array}{c}-0.036^{* *} \\
{[0.017]}\end{array}$ & $\begin{array}{c}-0.057 * * * \\
{[0.018]}\end{array}$ & $\begin{array}{c}0.045 \\
{[0.030]}\end{array}$ & $\begin{array}{l}0.077^{* *} \\
{[0.031]}\end{array}$ \\
\hline Real Interest Rate & $\begin{array}{l}-3.555 \\
{[3.158]}\end{array}$ & $\begin{array}{c}-0.400 * * * \\
{[0.050]}\end{array}$ & $\begin{array}{l}-0.049 \\
{[0.044]}\end{array}$ & $\begin{array}{c}-0.072 * * * \\
{[0.027]}\end{array}$ & $\begin{array}{c}0.075 \\
{[0.077]}\end{array}$ & $\begin{array}{c}0.493 * * * \\
{[0.057]}\end{array}$ & $\begin{array}{c}0.086^{* * *} \\
{[0.023]}\end{array}$ & $\begin{array}{c}0.085^{* * *} \\
{[0.023]}\end{array}$ & $\begin{array}{l}-0.032 * \\
{[0.017]}\end{array}$ & $\begin{array}{c}-0.026^{*} \\
{[0.015]}\end{array}$ & $\begin{array}{c}0.123^{* * *} \\
{[0.030]}\end{array}$ & $\begin{array}{c}0.078^{* * *} \\
{[0.026]}\end{array}$ \\
\hline Foreign Direct Inv. & $\begin{array}{l}-0.570 \\
{[0.637]}\end{array}$ & $\begin{array}{l}0.059^{*} \\
{[0.032]}\end{array}$ & $\begin{array}{l}-0.047^{*} \\
{[0.029]}\end{array}$ & $\begin{array}{c}-0.113^{* * *} \\
{[0.017]}\end{array}$ & $\begin{array}{l}-0.052 \\
{[0.042]}\end{array}$ & $\begin{array}{c}-0.123 * * * \\
{[0.036]}\end{array}$ & $\begin{array}{c}-0.814 * * * \\
{[0.237]}\end{array}$ & $\begin{array}{c}0.144^{* * *} \\
{[0.191]}\end{array}$ & $\begin{array}{c}-0.639 * * * \\
{[0.163]}\end{array}$ & $\begin{array}{c}-0.635 * * * \\
{[0.125]}\end{array}$ & $\begin{array}{c}-1.636^{* * *} \\
{[0.282]}\end{array}$ & $\begin{array}{c}-1.334 * * * \\
{[0.212]}\end{array}$ \\
\hline GDP Growth & $\begin{array}{c}4.316 \\
{[5.040]}\end{array}$ & $\begin{array}{c}-0.721^{* * *} \\
{[0.057]}\end{array}$ & $\begin{array}{l}0.119^{*} \\
{[0.069]}\end{array}$ & $\begin{array}{c}0.341^{* * * *} \\
{[0.031]}\end{array}$ & $\begin{array}{c}-0.648 * * * \\
{[0.142]}\end{array}$ & $\begin{array}{c}0.322 * * * \\
{[0.064]}\end{array}$ & $\begin{array}{c}0.037 \\
{[0.101]}\end{array}$ & $\begin{array}{c}-0.090^{* * *} \\
{[0.107]}\end{array}$ & $\begin{array}{c}0.289 * * * \\
{[0.068]}\end{array}$ & $\begin{array}{c}0.260 * * * \\
{[0.072]}\end{array}$ & $\begin{array}{c}0.113 \\
{[0.116]}\end{array}$ & $\begin{array}{c}0.398^{* * *} \\
{[0.122]}\end{array}$ \\
\hline Savings & $\begin{array}{c}1.581 \\
{[1.294]}\end{array}$ & $\begin{array}{c}0.289 * * * \\
{[0.023]}\end{array}$ & $\begin{array}{c}-0.011 \\
{[0.018]}\end{array}$ & $\begin{array}{l}-0.003 \\
{[0.012]}\end{array}$ & $\begin{array}{c}0.362^{* * *} \\
{[0.053]}\end{array}$ & $\begin{array}{c}-0.329 * * * \\
{[0.026]}\end{array}$ & $\begin{array}{l}-0.168 \\
{[0.135]}\end{array}$ & $\begin{array}{c}-0.170^{* * *} \\
{[0.169]}\end{array}$ & $\begin{array}{c}-0.124 \\
{[0.094]}\end{array}$ & $\begin{array}{c}-0.151^{* * *} \\
{[0.105]}\end{array}$ & $\begin{array}{l}-0.319 * \\
{[0.170]}\end{array}$ & $\begin{array}{c}-0.151^{* * *} \\
{[0.180]}\end{array}$ \\
\hline Constant & $\begin{array}{c}2.399 \\
{[2.012]}\end{array}$ & $\begin{array}{c}0.390 * * * \\
{[0.014]}\end{array}$ & $\begin{array}{c}0.114 * * * \\
{[0.013]}\end{array}$ & $\begin{array}{c}0.094^{* * *} \\
{[0.007]}\end{array}$ & $\begin{array}{c}0.409 * * * \\
{[0.064]}\end{array}$ & $\begin{array}{c}0.096 * * * \\
{[0.015]}\end{array}$ & $\begin{array}{c}0.391^{* * * *} \\
{[0.039]}\end{array}$ & $\begin{array}{c}0.404^{* * *} \\
{[0.042]}\end{array}$ & $\begin{array}{c}0.110^{* * *} \\
{[0.027]}\end{array}$ & $\begin{array}{c}-1.902 * * * \\
{[0.028]}\end{array}$ & $\begin{array}{c}0.609 * * * \\
{[0.051]}\end{array}$ & $\begin{array}{c}0.042^{* * *} \\
{[0.047]}\end{array}$ \\
\hline Industry Dummies & Yes & Yes & Yes & Yes & Yes & Yes & Yes & Yes & Yes & Yes & Yes & Yes \\
\hline Time Dummies & Yes & Yes & Yes & Yes & Yes & Yes & Yes & Yes & Yes & Yes & Yes & Yes \\
\hline $\mathrm{N}$ & 53,925 & 53,925 & 54,872 & 54,872 & 57,247 & 57,247 & 8,753 & 8,753 & 8,801 & 8,801 & 9,169 & 9,169 \\
\hline Model R ${ }^{2}$ & 0.01 & & 0.12 & & 0.10 & & 0.08 & & 0.14 & & 0.12 & \\
\hline Model $\chi^{2}$ & & $4708 * * *$ & & $7778 * * *$ & & $4737 * * *$ & & $941 * * *$ & & $1751^{* * *}$ & & $796^{* * *}$ \\
\hline
\end{tabular}

Notes. The following robust OLS regression is specified: (Short-term/Long-term/Total) $L e v_{i, t}=\varphi_{0}+\varphi_{1} F P I_{i t-1}+\varphi_{2} X_{i, t-1}+\varphi_{3} Y_{j,-1}+\varphi_{4} I_{i}+\varphi_{5} t+\varepsilon$. Specifications (1) and (4) use short-term leverage scaled by total assets as the dependent variable. Specifications (2) and (5) use long-term leverage scaled by total assets as the dependent variable. Specifications (3) and (6) use total liabilities scaled by total assets as the dependent variable. Development subsamples are based on the level of property rights in a nation. FPI is foreign portfolio investment standardized by gross domestic product and represents

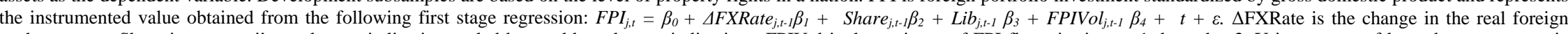
exchange rate. Share is country j's market capitalization scaled by world market capitalization. FPIVol is the variance of FPI flows in times t-1 through t-3. Y is a vector of lagged macroeconomic variables including the following: GDP Growth is the growth rate in gross domestic product of country j. Foreign Direct Inv. is the level of foreign direct investment scaled by its GDP. Savings is the difference between GDP and consumption, scaled by GDP. Fiscal Burden is a measure of the level of taxes usurped by the government from corporations from 1 (fewer taxes) to 5 (higher taxes). Real Int. Rates is country j's interest rate adjusted for inflation. X is a vector of lagged firm-specific variables such as cash flow, debt/asset level, risk, profitability, and asset tangibility. I is a vector of industry dummies to control for industry effects and t represents time dummies, which control for any time effects in the panel. Observations are firm year specific and for the term 1996-2005. Firm level control variables are left out for brevity. Robust standard errors clustered around issuer and are in brackets.

* Significance at the $10 \%$ level.

** Idem, $5 \%$

*** Idem, $1 \%$. 
Table 8. Robustness

\begin{tabular}{|c|c|c|c|c|c|c|c|c|c|c|}
\hline \multirow{5}{*}{ Dep. Variable } & \multicolumn{5}{|c|}{ Developed Property Rights Nations } & \multicolumn{5}{|c|}{ Less Developed Property Rights Nations } \\
\hline & \multirow{2}{*}{\multicolumn{2}{|c|}{$\begin{array}{c}\text { Capital Markets } \\
\text { Capital Issuance Dummy }\end{array}$}} & \multirow{3}{*}{$\begin{array}{c}\text { Short-term } \\
\text { Debt }\end{array}$} & \multirow{3}{*}{$\begin{array}{c}\text { Debt } \\
\begin{array}{c}\text { Long-Term } \\
\text { Debt }\end{array} \\
\end{array}$} & \multirow[b]{3}{*}{ Total Debt } & \multirow{2}{*}{\multicolumn{2}{|c|}{$\begin{array}{c}\text { Capital Markets } \\
\text { Capital Issuance Dummy } \\
\end{array}$}} & \multicolumn{3}{|c|}{ Debt } \\
\hline & & & & & & & & \multirow{2}{*}{$\begin{array}{c}\text { Short-term } \\
\text { Debt }\end{array}$} & \multirow{2}{*}{$\begin{array}{l}\text { Long-Term } \\
\text { Debt }\end{array}$} & \multirow[b]{2}{*}{ Total Debt } \\
\hline & Small Firms & Large Firms & & & & Small Firms & Large Firms & & & \\
\hline & 1 & 2 & 3 & 4 & 5 & 6 & 7 & 8 & 9 & 10 \\
\hline Expected Sign & + & - & Insignificant & + & + & + & - & - & - & - \\
\hline \multicolumn{11}{|c|}{ Panel A: Key Variable Definition } \\
\hline \multicolumn{11}{|c|}{ 1. FPI Net Flow scaled by Gross Private Capital Flows } \\
\hline FPI & $\begin{array}{c}34.563^{* * *} \\
{[9.794]}\end{array}$ & $\begin{array}{c}-87.481^{* * *} \\
{[10.559]}\end{array}$ & $\begin{array}{c}301.717 \\
{[302.169]}\end{array}$ & $\begin{array}{c}7.508 * * * \\
{[2.059]}\end{array}$ & $\begin{array}{c}6.133^{* *} \\
{[6.882]}\end{array}$ & $\begin{array}{c}11.233 \\
{[14.257]}\end{array}$ & $\begin{array}{c}-77.403^{* * *} \\
{[19.024]}\end{array}$ & $\begin{array}{c}-88.443 * * * \\
{[11.079]}\end{array}$ & $\begin{array}{c}-24.325^{* * *} \\
{[6.970]}\end{array}$ & $\begin{array}{c}-130.270 * * * \\
{[13.112]}\end{array}$ \\
\hline Observations & 57,153 & 43,977 & 53,834 & 54,778 & 57,153 & 9,169 & 6,772 & 8,753 & 8,801 & 9,169 \\
\hline Pseudo $\mathrm{R}^{2} / \mathrm{R}^{2}$ & 0.238 & 0.208 & 0.000 & 0.126 & 0.097 & 0.069 & 0.220 & 0.001 & 0.130 & 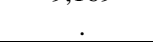 \\
\hline \multicolumn{11}{|c|}{ 2. FPI scaled by GDP winsorized at $1 \%$} \\
\hline \multirow[t]{2}{*}{ FPI } & $0.336^{* * *}$ & $-0.329 * * *$ & 4.843 & $0.135^{* * *}$ & $0.313^{* * *}$ & $3.390 * * *$ & $-10.584 * * *$ & $-2.561 * * *$ & $-1.566 * * *$ & $-4.472 * * *$ \\
\hline & {$[0.063]$} & [0.111] & [4.796] & {$[0.032]$} & {$[0.103]$} & [0.493] & [2.957] & {$[0.560]$} & {$[0.413]$} & [0.659] \\
\hline Observations & 57,247 & 44,058 & 53,925 & 54,872 & 57,247 & 9,169 & 6,772 & 8,753 & 8,801 & 9,169 \\
\hline Pseudo $\mathrm{R}^{2} / \mathrm{R}^{2}$ & 0.206 & 0.069 & 0.000 & 0.124 & 0.100 & 0.213 & 0.220 & 0.084 & 0.144 & 0.121 \\
\hline \multicolumn{11}{|c|}{ 3. Percentage Change in FPI Net Flow } \\
\hline \multirow[t]{2}{*}{ FPI } & $0.016^{* * *}$ & $-0.060 * * *$ & 0.242 & $0.008^{* * *}$ & $0.017 * * *$ & $0.002 * * *$ & 0.001 & $-0.002 * * *$ & $-0.001 * * *$ & $-0.004 * * *$ \\
\hline & [0.004] & [0.004] & [0.239] & {$[0.002]$} & {$[0.006]$} & {$[0.001]$} & [0.001] & {$[0.000]$} & {$[0.000]$} & {$[0.001]$} \\
\hline Observations & 56,991 & 43,799 & 53,669 & 54,613 & 56,991 & 9,739 & 6,764 & 9,313 & 9,339 & 9,739 \\
\hline Pseudo $\mathrm{R}^{2} / \mathrm{R}^{2}$ & 0.205 & 0.069 & 0.000 & 0.009 & 0.001 & 0.252 & 0.218 & 0.090 & 0.171 & 0.146 \\
\hline \multicolumn{11}{|c|}{ 4. FPI Volatility based on five-year term } \\
\hline \multirow[t]{2}{*}{ FPI } & $0.310^{* * *}$ & $-0.456 * * *$ & 5.379 & $0.163 * * *$ & $0.448 * * *$ & $3.067 * * *$ & $-9.883^{* * *}$ & $-2.493 * * *$ & $-1.425^{* * *}$ & $-4.357 * * *$ \\
\hline & {$[0.073]$} & [0.117] & [5.264] & [0.042] & [0.104] & {$[0.544]$} & {$[3.216]$} & {$[0.580]$} & {$[0.435]$} & {$[0.676]$} \\
\hline Observations & 56,919 & 43,799 & 53,607 & 54,544 & 56,919 & 9,157 & 6,739 & 8,741 & 8,789 & 9,157 \\
\hline Pseudo $\mathrm{R}^{2} / \mathrm{R}^{2}$ & 0.206 & 0.213 & 0.000 & 0.123 & 0.098 & 0.069 & 0.220 & 0.085 & 0.148 & 0.123 \\
\hline \multicolumn{11}{|c|}{ Panel B: Sample Inclusion } \\
\hline \multicolumn{11}{|c|}{ 1. Excluding countries with capital control changes } \\
\hline \multirow[t]{2}{*}{ FPI } & $0.148^{* * *}$ & $-0.384 * * *$ & 5.850 & $0.132 * * *$ & $0.226^{* * *}$ & $1.539 * * *$ & $-2.210^{* * *}$ & $1.169 * * *$ & -0.132 & $1.390^{* * *}$ \\
\hline & {$[0.055]$} & [0.072] & [4.466] & [0.025] & [0.045] & [0.224] & [0.613] & [0.344] & [0.263] & [0.411] \\
\hline Observations & 53,743 & 40,868 & 50,629 & 51,441 & 53,743 & 6,179 & 4,559 & 5,847 & 5,952 & 6,179 \\
\hline Pseudo $\mathrm{R}^{2} / \mathrm{R}^{2}$ & 0.236 & 0.324 & 0.001 & 0.129 & 0.162 & 0.076 & 0.252 & 0.125 & 0.135 & 0.169 \\
\hline \multicolumn{11}{|c|}{ 2. Bottom third of total assets by country-year } \\
\hline FPI & $0.426 * * *$ & $-0.161 *$ & 4.905 & $0.107 * * *$ & $0.458 * * *$ & $3.678 * * *$ & $-2.961 * *$ & 2.847 & $-1.941 *$ & $-3.863 * *$ \\
\hline & [0.153] & [0.095] & [4.843] & [0.033] & [0.069] & [0.961] & [1.416] & [2.144] & [1.021] & [1.819] \\
\hline Observations & 28,918 & 45,240 & 27,058 & 28,361 & 28,931 & 4,517 & 6,492 & 4,312 & 4,392 & 4,518 \\
\hline Pseudo $\mathrm{R}^{2} / \mathrm{R}^{2}$ & 0.359 & 0.390 & 0.001 & 0.080 & 0.179 & 0.072 & 0.246 & 0.086 & 0.097 & 0.162 \\
\hline
\end{tabular}


Table 8. Robustness (Continued)

\begin{tabular}{|c|c|c|c|c|c|c|c|c|c|c|}
\hline \multirow{5}{*}{ Dep. Variable } & \multicolumn{5}{|c|}{ Developed Property Rights Nations } & \multicolumn{5}{|c|}{ Less Developed Property Rights Nations } \\
\hline & \multirow{2}{*}{\multicolumn{2}{|c|}{$\begin{array}{c}\text { Capital Markets } \\
\text { Capital Issuance Dummy } \\
\end{array}$}} & \multirow{3}{*}{$\begin{array}{c}\text { Short-term } \\
\text { Debt }\end{array}$} & \multicolumn{2}{|l|}{ Debt } & \multirow{2}{*}{\multicolumn{2}{|c|}{$\begin{array}{c}\text { Capital Markets } \\
\text { Capital Issuance Dummy } \\
\end{array}$}} & \multicolumn{3}{|c|}{ Debt } \\
\hline & & & & Lona-Term & & & & \multirow{2}{*}{$\begin{array}{c}\begin{array}{c}\text { Short-term } \\
\text { Debt }\end{array} \\
\end{array}$} & \multirow{2}{*}{$\begin{array}{c}\text { Long-Term } \\
\text { Debt }\end{array}$} & \multirow[b]{2}{*}{ Total Debt } \\
\hline & Small Firms & Large Firms & & Debt & Total Debt & Small Firms & Large Firms & & & \\
\hline & 1 & 2 & 3 & 4 & 5 & 6 & 7 & 8 & 9 & 10 \\
\hline Expected Sign & + & - & Insignificant & + & + & + & - & - & - & - \\
\hline \multicolumn{11}{|c|}{ 3. Only Equity Issues } \\
\hline \multirow[t]{2}{*}{ FPI } & $0.191^{* * *}$ & $-0.278^{* *}$ & 4.998 & $0.127 * * *$ & $0.312^{* * *}$ & $1.833^{* * *}$ & $-10.584^{* * *}$ & $-2.459 * * *$ & $-1.709 * * *$ & $-4.393 * * *$ \\
\hline & {$[0.054]$} & {$[0.111]$} & [4.943] & [0.032] & {$[0.106]$} & {$[0.480]$} & [2.877] & [0.575] & {$[0.421]$} & {$[0.664]$} \\
\hline Observations & 55,792 & 44,058 & 52,495 & 53,431 & 55,792 & 9,045 & 6,772 & 8,629 & 8,677 & 9,045 \\
\hline Pseudo $\mathrm{R}^{2} / \mathrm{R}^{2}$ & 0.217 & 0.069 & 0.000 & 0.128 & 0.102 & 0.242 & 0.220 & 0.085 & 0.149 & 0.126 \\
\hline \multicolumn{11}{|c|}{ Panel C: Methodology } \\
\hline \multicolumn{11}{|c|}{ 1. Clustered Errors at Industry Level } \\
\hline \multirow[t]{2}{*}{ FPI } & $0.326 * * *$ & $-0.277 * *$ & 4.969 & 0.124 & $0.350 *$ & $3.388 * * *$ & $-16.479 * * *$ & $-2.510 * * *$ & $-1.585^{* * *}$ & $-4.431^{* * *}$ \\
\hline & {$[0.068]$} & {$[0.110]$} & {$[4.706]$} & {$[0.074]$} & {$[0.159]$} & {$[0.258]$} & [3.966] & [0.497] & {$[0.377]$} & {$[0.550]$} \\
\hline Observations & 57,247 & 44,058 & 53,925 & 54,872 & 57,247 & 9,169 & 6,772 & 8,753 & 8,801 & 9,169 \\
\hline Pseudo $\mathrm{R}^{2} / \mathrm{R}^{2}$ & 0.202 & 0.209 & 0.000 & 0.092 & 0.090 & 0.063 & 0.213 & 0.077 & 0.134 & 0.117 \\
\hline \multicolumn{11}{|c|}{ 2: Country Dummies } \\
\hline \multirow[t]{2}{*}{ FPI } & $0.305^{* * *}$ & $-0.388 * *$ & 14.005 & -0.117 & $0.713^{* * *}$ & $3.398 * * *$ & $-3.127 * *$ & $-1.801^{*}$ & 0.245 & $-1.868^{*}$ \\
\hline & {$[0.107]$} & [0.189] & [13.097] & {$[0.076]$} & {$[0.183]$} & {$[0.548]$} & [1.402] & [1.091] & {$[0.568]$} & {$[0.977]$} \\
\hline Observations & 54,660 & 43,145 & 53,924 & 54,871 & 57,247 & 9,103 & 6,772 & 8,753 & 8,801 & 9,169 \\
\hline Pseudo $\mathrm{R}^{2} / \mathrm{R}^{2}$ & 0.324 & & 0.001 & 0.152 & 0.107 & 0.235 & 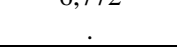 & 0.118 & 0.178 & 0.205 \\
\hline \multicolumn{11}{|c|}{ 3: Frequency Weights } \\
\hline FPI & $0.338^{* * *}$ & $-0.827 * * *$ & 4.849 & $0.134 * * *$ & $0.312 * * *$ & $3.390 * * *$ & $-2.68^{* * *}$ & $-2.561 * * *$ & $-1.566 * * *$ & $-4.472 * * *$ \\
\hline & {$[0.086]$} & {$[0.088]$} & {$[4.802]$} & {$[0.032]$} & {$[0.103]$} & {$[0.556]$} & {$[0.979]$} & {$[0.560]$} & {$[0.413]$} & {$[0.659]$} \\
\hline Observations & 57,247 & 63,510 & 53,925 & 54,872 & 57,247 & 9,169 & 9,435 & 8,753 & 8,801 & 9,169 \\
\hline Pseudo $\mathrm{R}^{2} / \mathrm{R}^{2}$ & 0.206 & 0.213 & 0.000 & 0.124 & 0.100 & 0.150 & 0.521 & 0.084 & 0.144 & 0.121 \\
\hline
\end{tabular}

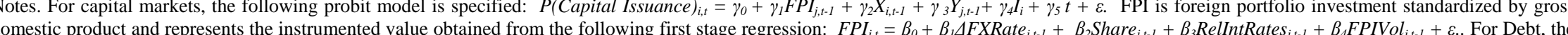
following robust OLS regression is specified: (Short-term/Long-term/Total) $L e v_{i, t}=\varphi_{0}+\varphi_{1} F P I_{i, t-1}+\varphi_{2} X_{i, t-1}+\varphi_{3} Y_{j, t-1}+\varphi_{4} I_{i}+\varphi_{5} t+\varepsilon$. Specifications (3) and (8) use short-term leverage scaled by total assets as the dependent variable. Specifications (4) and (9) use long-term leverage scaled by total assets as the dependent variable. Specifications (5) and (10) use total liabilities scaled by total assets as the dependent variable. Development sub samples are based on the level of property rights in a nation. FPI is foreign portfolio investment standardized by gross domestic product and represents the instrumented value obtained from the following first stage regression: $F P I_{j, t}=\beta_{0}+\Delta F X$ Rate $_{j, t-1} \beta_{1}+$ Share $_{j, t-1} \beta_{2}+$ Lib $_{j, t-1} \beta_{3}+$ FPIVol $_{j, t-1} \beta_{4}+t+\varepsilon$. X is a vector of lagged firm-specific variables such as cash flow, debt/asset level, risk, profitability, and asset tangibility. $\Delta$ FXRate is the change in the real foreign exchange rate. Share is country j's market capitalization scaled by world market capitalization. RelIntRates are the annual real interest rates of country j scaled by sample average calculated annually. FPIVol is the variance of FPI flows in times t-1 through t-3. Y is a vector of lagged macroeconomic variables including the following: GDP Growth, Foreign Direct Inv., Domestic Credit, Savings. For Debt regressions, Y also includes Fiscal Burden and Real Int.Rates. I is a vector of industry dummies to control for industry effects (in all specifications except those clustered by industry) and t represents time dummies, which control for any time effects in the panel (in all specifications). Panel A examines different key variable definitions. Panel B examines different sample inclusion criteria. Panel C examines different methodology extrapolations. Observations are firmyear specific and for the term 1996-2005. Control variables are left out for brevity. Robust standard errors are in brackets. Marginal effects of the variables are provided.

* Significance at the $10 \%$ level.

* Idem, $5 \%$

*** Idem, $1 \%$. 
Figure I. Scatter Plots of FPI and Capital Issuance

\section{Nations with Developed Property Rights}

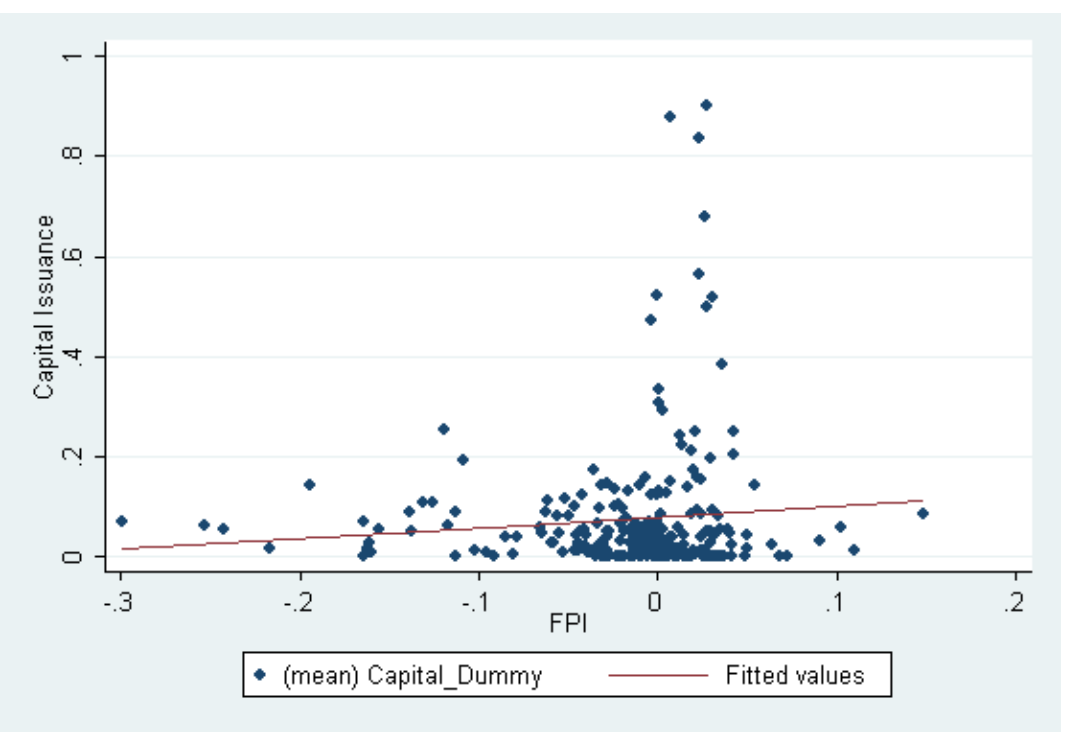

\section{Nations with Less Developed Property Rights}

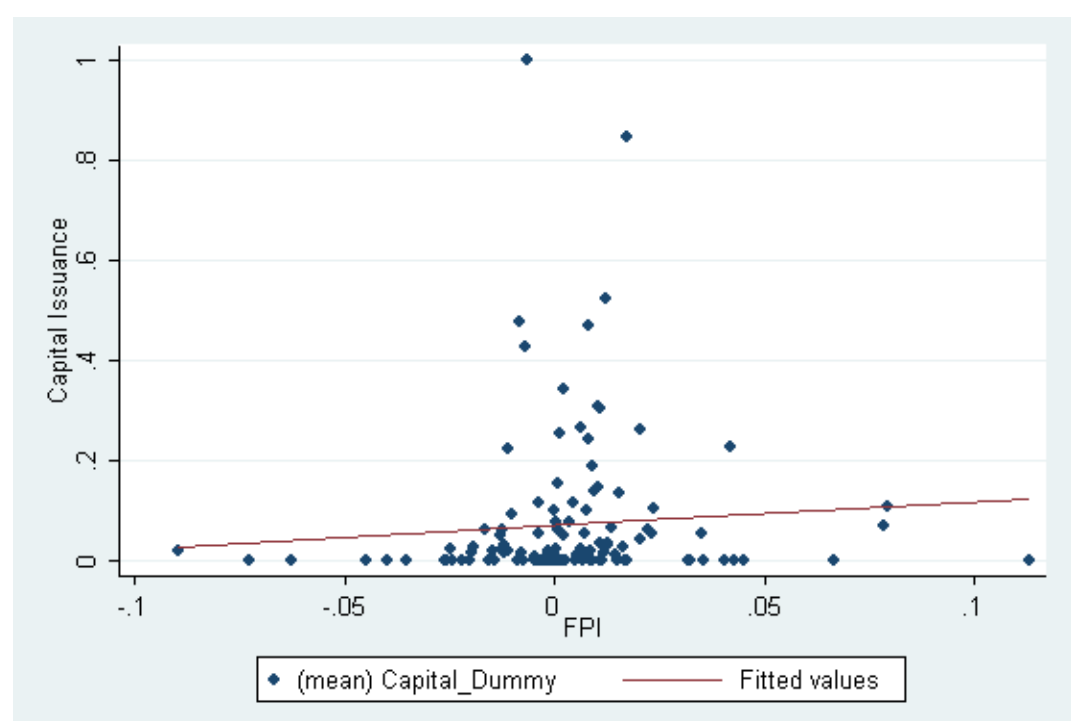

Notes. These graphs are partial scatter plots obtained from Specification 1 in Table 4: $P(\text { Capital Issuance })_{i, t}=\gamma_{0}+F P I_{j, t-1} \gamma_{1}+$ $X_{i, t-1} \gamma_{2}+Y_{j, t-1} \gamma_{3}+I_{i}+t+\varepsilon$. Nations with (less) developed property rights are those with property rights indices equal to a " 1 ” or “2” (“3” or “4”). For tractability, each dot represents a country-year. 